\title{
ANÁLISE MORFOLÓGICA DA MATRIZ DO ESMALTE \\ EM INCISIVOS DE RATOS SUBMETIDOS À FLUOROSE
}

MARIA RENATA SALES NOGUEIRA COSTA

Dissertação apresentada à Faculdade de Odontologia de Bauru, Universidade de São Paulo, como parte dos requisitos para a obtenção do título de Mestre em Odontologia, área de Patologia Bucal.

(Edição Revisada)

BAURU

2000 


\section{ANÁLISE MORFOLÓGICA DA MATRIZ DO ESMALTE \\ EM INCISIVOS DE RATOS SUBMETIDOS À FLUOROSE}

MARIA RENATA SALES NOGUEIRA COSTA

Dissertação apresentada à Faculdade de Odontologia de Bauru, Universidade de São Paulo, como parte dos requisitos para a obtenção do título de Mestre em Odontologia, área de Patologia Bucal.

(Edição Revisada)

Orientador :

PROF. DR. GERSON FRANCISCO DE ASSIS

BAURU

2000 


\section{Ficha Técnica}

Concepção original, experimento, redação, digitação, formatação, imunohistoquímica: Maria Renata Sales Nogueira Costa.

Concepção original, orientação geral, estatística, revisão final: Gerson Francisco de Assis.

Perfusão, fotografias, densitometria: Tânia Mary Cestari

Histotécnica: Danielle Santi Ceolin

Capa, cópias e encadernação: Marcus Thame

Revisão final do vernáculo: Valdir João Afonso

Costa, Maria Renata Sales Nogueira

C823a Análise morfológica da matriz do esmalte em incisivos de ratos submetidos à fluorose. / Maria Renata Sales Nogueira Costa - Bauru, 2000.

125p: il.; $28 \mathrm{~cm}$.

Dissertação. (Mestrado) - Faculdade de Odontologia de Bauru. USP.

Orientador: Prof. Dr. Gerson Francisco de Assis 


\section{MARIA RENATA SALES NOGUEIRA COSTA}

Cinco de março de 1971-Bauru. SP

Filiação

1989-1994

1996-1998

$1998-2000$

1999-1999

$2000-2000$

2000

Associações
Nascimento

José Martins Nogueira

Angela de Quadros Sales Nogueira

Curso de Graduação em Odontologia pela Universidade de Marília. Marília$S P$

Curso de Especialização em Endodontia pelo Hospital de Anomalias Craniofaciais da Universidade de São Paulo. Bauru-SP

Mestrado em Patologia Bucal pela Faculdade de Odontologia de Bauru, Universidade de São Paulo. Bauru-SP

Professora Colaboradora da Disciplina de Patologia Geral do Curso de Fonoaudiologia da Faculdade de Filosofia e Ciências, da Universidade Estadual Paulista. Marilia-SP

Professora da Disciplina de Patologia Bucal da Faculdade de Odontologia da Universidade Metodista de Piracicaba. Lins-SP

Professora das Disciplinas de Patologia $e$ Estomatologia do Curso de Odontologia da Universidade Estadual do Oeste do Paraná. Cascavel-PR

Sociedade Brasileira de Pesquisa Odontológica 


\section{“Las manos de mi Madre parecen pajaros en el aire, Me representan un cielo abierto y um recuerdo a ñorado, Trapos calientes en los inviernos ellas se brindan calidas, nobles, sinceras Limpias de todo."}

(Peteco Carabajal)

Dedico esse trabalho a minha Mãe ANGELA a dona dessas mãos tão nobres 


\title{
Dedico a JOSÉ (in memoriam) e FÁBIO
}

\author{
Meus queridos pai e esposo
}

\section{Trazem-me força e paz,} por me dedicarem a proteção do vosso amor, que aquece continuamente o meu coração 
Para minhas crianças

\section{LUCAS e HELENA}

"Se eu pudesse deixar algum presente a você, deixaria o acesso ao sentimento de amor à vida dos seres humanos.

A consciência de aprender tudo que nos foi ensinado pelo tempo afora, lembraria dos erros que foram cometidos, como sinais para que não mais se repetissem.

A capacidade de escolher novos rumos, deixaria para você se pudesse, o respeito àquilo que é indispensável: além do pão, o trabalho, a ação.

E quando tudo mais faltasse para você, eu deixaria, se pudesse, um segredo:

o de buscar no interior de si mesmo o respeito e a força para encontrar a saída." 
AGRADECIMENTOS 
"A ciência nos ensina a curar e a matar, reduz a taxa de mortalidade no varejo

depois nos mata por atacado na guerra;

\author{
Mas só a sabedoria \\ - o desejo coordenado à luz do conhecimento - \\ pode nos dizer quando curar e quando matar. "
}

(Will Durant)

Agradeço ao meu admirável Orientador, GERSON FRANCISCO DE ASSIS,

por compartilhar sem restrições esse "desejo coordenado à luz do conhecimento", que poucos possuem e pouquíssimos dividem. 
Certa vez, ouvi uma professora dizer que a gratidão pode ser vista, do plano espiritual, como raras flores em um prado verde. Ela estava certa, a gratidão realmente é rara e preciosa na humanidade. Deve ser praticada para que brotem mais dessas flores. Quero deixar algumas delas para as pessoas que fizeram parte deste segmento inesquecível em minha vida.

Renata 
Minha enorme gratidão aos meus irmãos e irmãs, FRANCISCO, NOGUEIRA, ANGELA e ESTHER

\author{
Por serem de fato irmãos, \\ algumas vezes pais. \\ Pais zelosos que me mostraram \\ como viver e amar
}

Agradeço ao meu cunhado e cunhadas, NETO, EDNÉIA e PÉROLA

Que contribuíram, como irmãos, para minha formação moral e me trouxeram a luz de seus filhos, meus amados sobrinhos e sobrinhas Maurício, Eduardo, Gustavo, Andréa, Thaís, Patrícia, Rafaela e Raquel 
Agradeço ao Professor Doutor James P. Simmer, do Departamento de Odontologia Pediátrica da Universidade do Texas, San Antonio, USA. Sem sua preciosa contribuição, ao doar os anticorpos primários para amelogeninas, este experimento não existiria. Sem gestos como esse, a ciência não seria a mesma.

Ao Professor Doutor Alberto Consolaro, Titular da Disciplina de Patologia da Faculdade de Odontologia da Universidade de São Paulo (FOB-USP), sou grata por ser um verdadeiro mestre e por me contagiar com seu imenso amor à patologia.

Ao Professor Doutor Eduardo Alvares Dainesi, Responsável pela Disciplina de Ortodontia do Curso de Odontologia da Universidade Estadual do Oeste do Paraná (UNIOESTE), agradeço pelo privilégio de tê-lo como amigo e poder contar com sua exemplar capacidade profissional. 
Agradeço aos Professores Doutores Luís Antôn io de Assis Taveira, Denise Tostes Oliveira, Vanessa Soares Lara, da Disciplina de Patologia e Antonio Carlos Marconi Stipp, da Disciplina de Histologia da FOB-USP, pelo incentivo, carinho e por muitos bons conselhos.

Agradeço aos Professores do Curso de Odontologia da UNIOESTE, em especial, Adriano Tomio Hishi, Carlos Augusto Nassar, Christian Giampietro Brandão, Eduardo Tanaka de Castro, José Neto da Costa, Júlio Katuhide Ueda, Luiz Alberto Formighieri, Roberto Bombonatti e Sílvia Soares Lemos, por se tornarem queridos amigos e sempre estarem ao meu lado.

Agradeço ao Coordenador e à Vice-Coordenadora do Curso de Odontologia da UNIOESTE, Professor Rolando Plümer Peezzini e Professora Doutora Fabiana Scarparo Naufel, pela confiança e incentivo. 
Aos Professores Doutores Marília Afonso Rabello

Buzalaf e José Mauro Granjeiro; e à funcionária Thelma Lopes da Silva, da Disciplina de Bioquímica, sou grata pelas orientações que recebi nesse campo tão fascinante da ciência.

Agradeço aos Professores Doutores Sérgio Roberto Peres Line e Pedro Duarte Novaes, do Departamento de Morfologia da Faculdade de Odontologia de Piracicaba-UNICAMP, bem como às pós-graduandas Mitsue Fujimaki e Raquel Fernanda Gerlach. Que nos receberem de forma tão calorosa nessa Instituição e contribuíram com importantíssimas orientações referentes à experimentação inicial deste trabalho.

Agradeço ao Doutor Cleverson Teixeira Soares e à equipe técnica do Laboratório de Anatomia Patológica e Citopatologia de Bauru, que muito gentilmente realizaram o teste piloto nos anticorpos prim ários para amelogeninas. 
O meu enorme carinho e agradecimento às amigas, Márcia, Regina, Marianne, Mariza, Fernanda e M ônica, pós-graduandas da Disciplina de Patologia da FOB-USP, que compõem uma das melhores lembranças que guardo e levo pela vida. E a todos os pós-graduandos desta Disciplina, por suas contribuições e companheirismo.

Agradeço aos funcionários da Disciplina de Patologia da FOB-USP, Valdir, Fátima, Bernadete e Cristina, que tanto contribuíram na realização desta tese e por serem sempre bons amigos;

Às funcionárias da disciplina de Histologia, em especial à Tânia e Daniele, porque foram maravilhosas e imprescindíveis para que este nosso trabalho se concretizasse; 
À Valéria Cristina Trindade Ferraz e demais funcionários da Biblioteca da FOB-USP, por contribuírem grandemente para a composição formal deste trabalho;

À Carmem, Aleks e Vera, funcionários do curso de Odontologia da UNIOESTE, pela colaboração profissional, pela consideração e carinho que me dedicam;

E ao André, funcionário da Disciplina da Microbiologia e Imunologia da FOB-USP, que sempre me dizia "não se preocupe, de repente, tudo vai dar certo!" 
Lista de Figuras.............................................................................. xix

Lista de Tabelas.............................................................................. xxi

Lista de Abreviaturas....................................................................... xxii

Resumo......................................................................................... xxiii

1. Introdução................................................................................ 1

2. Revisão da Literatura............................................................ 10

2.1. A matriz do esmalte - Estrutura e Cinética............................ 11

2.2. Os distúrbios do desenvolvimento do esmalte...................... 22

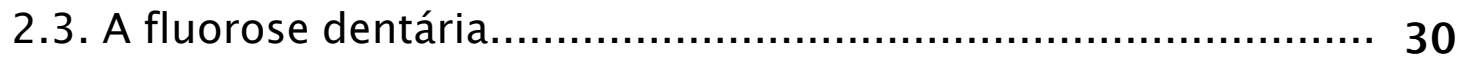

3. Proposição..................................................................................... 41

4. Material e Métodos...................................................................... 43

4.1. Seleção dos animais..................................................... 44 


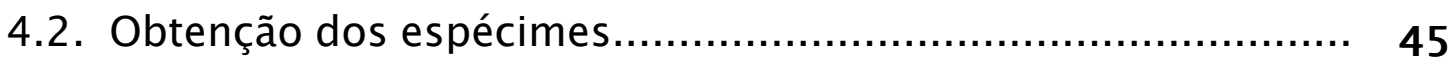

4.2.1. Grupo experimental I 45

4.2.2. Grupo experimental II 45

4.2.3. Grupo controle $\quad 46$

4.3. Processamento histotécnico......................................... 47

4.4. Imuno-histoquímica.................................................... 48

4.4.1. Material utilizado $\quad 48$

4.4.2. Padronização da técnica 49

4.5. Análise morfológica descritiva.......................................... 52

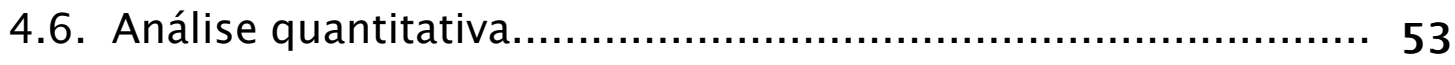

4.6.1. Comprimento linear da matriz do esmalte 53

4.6.2. Densidade da matriz do esmalte $\quad 54$

4.7. Tratamento estatístico................................................... 55

5. Resultados .................................................................................... 56

5.1. Massa corporal............................................................. 57

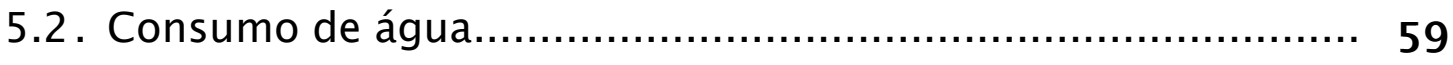

5.3. Morfologia macroscópica...............................................6 60

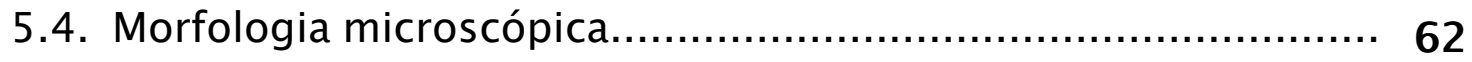

5.4.1. Análise descritiva $\quad 62$

5.4.2. Análise quantitativa 76

5.4.2.1. Comprimento linear da matriz do esmalte 76 
6. Discussão.

83

7.Conclusão.

101

Referências Bibliográficas

Abstract 


\section{Lista de Figuras}

Figura 1 - Aspecto clínico dos incisivos de ratos dos grupos I e II,

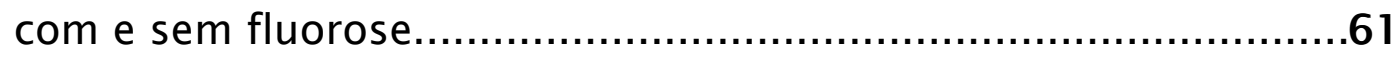

Figura 2 - Aspecto microscópico do corte longitudinal de um incisivo de rato do grupo de sete ppm, utilizado como controle negativo para a técnica imuno-histoquímica.

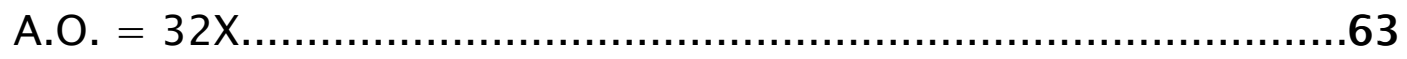

Figura 3 - Aspecto microscópico do corte longitudinal de um incisivo de rato do grupo de sete ppm. Imuno-histoquímica. A.O. = $32 X$ .64

Figura 4 A, B e C - Microscopia dos grupos de 100 ppm, sete ppm e tratado com água deionizada, respectivamente. Fase de transição corada por imuno-histoquímica.

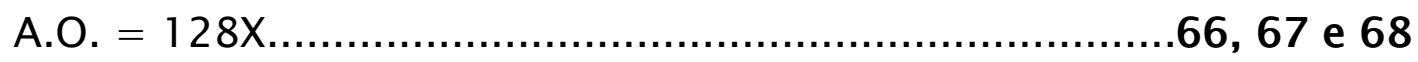


Figura 5 A, B e C - Grupos I, II e III em menor aumento, evidenciando as diferenças no comprimento da matriz do esmalte a partir da fase de transição. Imuno-histoquímica.

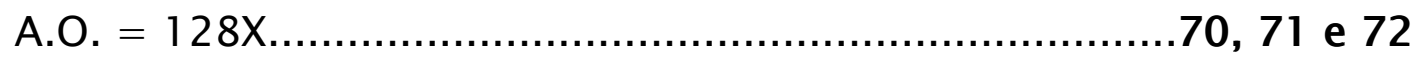

Figura 6 A, B e C - Aspectos microscópicos dos grupos de 100 ppm, sete ppm e controle. Fase de maturação, mostrando a morfologia da matriz em degradação. Imuno-histoquímica.

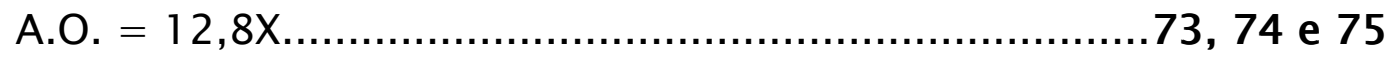

Figura 7 A e B - Dois aumentos microscópicos da matriz do incisivo de rato do grupo fluorótico (100 ppm), corados em H.E. para a mensuração da densidade óptica.

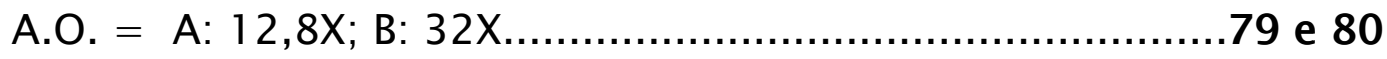




\section{Lista de Tabelas}

TABELA 1 - Índice DDE modificado, usado para estudos

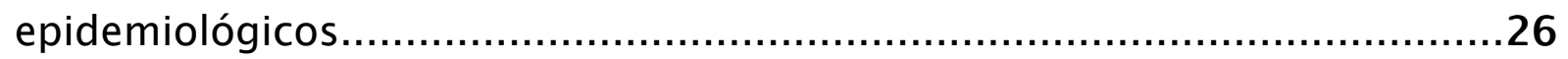

TABELA 2 - Médias semanais das massas corporais (em $\mathrm{mg}$ ) dos espécimes

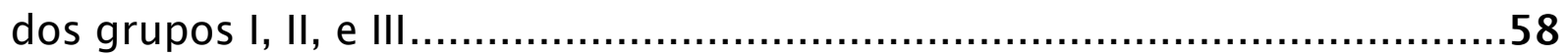

TABELA 3 - Média do consumo diário de água para cada animal dos grupos I, II e II 59

TABELA 4 - Médias do comprimento linear total e da fase de maturação das matrizes do esmalte de incisivos de ratos dos grupos I, II e III. Valores obtidos em milímetros. .77

TABELA 5 - Média e desvio padrão da densidade óptica da matriz do esmalte, em um ponto inicial $(0 \mu \mathrm{m})$ correspondente à fase de transição e em segmentos de $700 \mu \mathrm{m}$, previamente determinados ao longo da fase de maturação 


\section{Lista de Abreviaturas}

BSA - bovine serum albumine

DDE - developmental disturbances of enamel

FDA - food and drug administration

HE - hematoxilina e eosina

LRAP - leucine rich amelogenin protein

PBS - phosphate buffered salin

ppm - partes por milhão

TRAP - tirosine rich amelogenin protein 


\section{Resumo}

As amelogeninas representam o principal grupo de proteínas do esmalte e a sua retenção pós-transicional apresenta-se como um dos fatores relacionados à patogenia da fluorose dentária. O padrão de distribuição das amelogeninas, em dentes com fluorose, foi descrito por técnica imuno-histoquímica e o comprimento linear da matriz orgânica do esmalte foi determinado por análise morfométrica. Foram utilizados 15 ratos, divididos em três grupos e tratados com 100 ppm, sete ppm e com água deionizada, durante 42 dias. Os resultados obtidos por imunohistoquímica indicaram possíveis variações na exposição dos epítopos de amelogeninas, que foram evidenciadas de forma heterogênea. Os resultados da análise morfométrica permitiram a constatação de que não houve diferenças significantes entre os grupos tratados com $7 \mathrm{ppm}$ de fluoreto de sódio e com água deionizada ao longo da fase secretora da matriz, e que no grupo com fluorose induzida por $100 \mathrm{ppm}$, o comprimento linear da matriz foi $300 \%$ maior, em relação aos outros grupos testados. Observou-se ainda que, a densidade óptica da matriz orgânica manteve-se mais densa e homogênea após o início da fase de maturação do esmalte. Concluiu-se que, frente à metodologia adotada, $100 \mathrm{ppm}$ de fluoreto de sódio reservam a capacidade de reter as proteínas do esmalte ao longo da fase de maturação, onde deveriam ser clivadas e reabsorvidas, resultando em um padrão morfológico macroscópico de hipomineralização, característico da fluorose dentária 


\section{1 - INTRODU ÇÃO}




\section{1 . Introdução}

A odontogênese origina-se de eventos biológicos com notável peculiaridade. As células ectomesenquimais - migratórias da crista neural e as provenientes do ectoderma iniciam, por meio de uma relação de reciprocidade, a diferenciação dos rudimentos dos germes dentários nos processos maxilares do primeiro arco branquial embrionário. De acordo com estudos de recombinação tecidual, as células ectomesenquimais necessitam de um sinal local do epitélio ectodérmico para engajarem-se na odontogênese. O padrão de formação dentária poderia, deste modo, ser uma função iniciada no epitélio e transferida para o ectomesênquima ${ }^{46}$.

O epitélio ectodérmico, ao interagir com o tecido subjacente, prolifera-se gerando a lâmina dentária, onde se formarão, em pontos específicos, botões epiteliais, caracterizando 0 início do desenvolvimento odontogênico. A organização morfogenética do órgão do esmalte permite que se definam os contornos da futura coroa e o local de deposição inicial da matriz do esmalte ${ }^{90}$. 
Durante o período denominado capuz, o epitélio interno do órgão do esmalte torna-se discernível do externo. Subseqüentemente, na fase de campânula, suas células constituintes deixam de proliferar nas áreas cuspídeas. A citodiferenciação odontogênica se inicia no momento em que as células competentes do germe dentário respondem ao estímulo de fatores de crescimento específicos e alteram sua morfologia progressivamente, determinando as características fenotípicas das linhagens de ameloblastos e odontoblastos ${ }^{91}$.

Os pré-ameloblastos ou ameloblastos pré-secretores são células cuboidais que, a partir dos primeiros sinais de desenvolvimento odontogênico, tornam-se secretoras e morfologicamente colunares, com comprimento superior a $60 \mu \mathrm{m}$ e diâmetro de dois a três $\mu \mathrm{m}$. Seus núcleos e mitocôndrias polarizam-se no sentido proximal, enquanto a porção distal dessas células assume um aspecto cônico, constituindo o Processo de Tomes29; o único sítio celular a interagir com a superfície do esmalte, formado por meio da secreção de matriz orgânica, de sua remoção e de sua substituição por pequenos cristais minerais 57,66 .

A secreção de uma matriz aniônica macromolecular caracteriza o substrato para um processo denominado biomineralização. Durante 
esse fenômeno, formam-se estruturas cristalinas discretas e organizadas, que podem ser observadas em diferentes filos; desde moluscos e artrópodes até os cordados45. No grupo dos cordados, os mamíferos, os répteis, os peixes e os anfíbios possuem entre suas estruturas mineralizadas aquelas denominadas, esmalte e enamelóide. O esmalte presente nos mamíferos e nos répteis apresenta semelhanças em relação ao modo de remoção da matriz e a sua composição ${ }^{38}$. Em peixes e anfíbios, o enamelóide apresenta funções e localização similares ao esmalte, havendo em sua composição não só proteínas de origem embrionária ectodérmica, as amelogeninas, mas também oriundas do mesoderma36.

A matriz orgânica do esmalte de mamíferos não se forma exclusivamente por amelogeninas e, mesmo que em menor número, as proteínas não pertencentes a esse grupo têm sua importância e funções na formação do esmalte. TERMINE, em 1980, as identificou como enamelinas, perfazendo aproximadamente $5 \%$ do total das proteínas de matriz ${ }^{90}$. O termo enamelina chegou a ser utilizado de forma genérica referindo-se às proteínas classificadas como não-amelogeninas. Atualmente, sabe-se que nem todas não-amelogeninas são enamelinas, sendo tais proteínas pertencentes a um produto genético 
específico. Bioquimicamente, são glicoproteínas ácidas hidrofílicas, com isoformas variando entre $32-150 \mathrm{kDa}$ e que compartilham funções semelhantes as das amelogeninas 72 . As enamelinas possuem várias isoformas, mas sua constituição intacta, com $189 \mathrm{kDa}$, está restrita apenas à face secretora do Processo de Tomes 39 .

O esmalte em formação desenvolve uma porção prismática e outra interprismática. Esses dois tipos de estruturas são praticamente idênticos, a não ser pela angulação de seus cristais. Enquanto o esmalte prismático dispõe-se paralelamente ao longo eixo dos ameloblastos, o interprismático encontra-se a aproximadamente $65^{\circ} \mathrm{em}$ relação ao primeiro. Entre essas estruturas há uma camada delgada de matriz, sem cristais, conhecida como bainha do prisma ou espaço de bainha do prisma. Na amelogênese, o espaço referido pode ser observado desde a junção amelodentinária até a superfície do esmalte.

A alta concentração de proteínas residuais encontradas torna o esmalte mais susceptível à desmineralização, como a que ocorre em um processo carioso. As proteínas residentes no espaço da bainha foram denominadas sheathlins ${ }^{93}$ e receberam a tradução para a língua portuguesa de bainhelinas ${ }^{89}$. As bainhelinas extraídas de suínos foram 
clonadas, amplificadas e seqüenciadas por $\mathrm{HU}$ e seus colaboradores 39 , em 1997. Ao término de seu estudo, notaram que as seqüências de aminoácidos dessas proteínas suínas eram $66 \%$ idênticas as ameloblastinas de ratos. Quando comparadas por imuno-histoquímica, mostraram as mesmas modificações pós-translacionais e secretoras ${ }^{94}$, argumentos tidos como suficientes para que as ameloblastinas e as bainhelinas fossem ambas categorizadas como proteínas pertencentes ao espaço de bainha do prisma24. Pode-se encontrar o termo amelina como sinônimo de ameloblastina. No entanto, a segunda nomenclatura deve ser privilegiada, uma vez que amelina é a palavra usada para descrever uma proteína do tecido neural 39.

Estruturalmente, a molécula nascente das amelogeninas, de $25 \mathrm{kDa}^{59}$, compreende três regiões: uma seqüência terminal amina hidrófoba com seis a sete resíduos de tirosina, conhecida como TRAP tyrosine-rich amelogenin protein; um eixo central hidrófobo com 100130 resíduos, rico em prolina, leucina, metionina e glutamina; e uma porção terminal carboxila ácida hidrofílica, com 15 resíduos de aminoácidos 29 . 
O arranjo tridimensional do principal grupo de proteínas do esmalte, composto pelas amelogeninas, forma agregados de estruturas quaternárias quasi-esféricas denominadas nanosferas, cada uma com aproximadamente $20 \mathrm{~nm}$. Essas, como um "colar de pérolas" em torno dos cristalitos, assumem a função de andaime, direcionando o crescimento cristalino e modulando sua arquitetura ${ }^{32}$. Tais eventos ocorrem pela atuação inibitória das proteínas nas superfícies a e b dos cristais de apatita, possibilitando uma uniformidade em tamanho e morfologia, impedindo a invasão de um cristal sobre a superfície do outro e sua conseqüente fratura60,61.

Durante o período de maturação, a remoção ordenada das proteínas do esmalte, permite o crescimento de uma de suas superfícies cristalinas em maior proporção que as outras. Desse modo, há o alongamento de cada cristalito somente em seu eixo c, um processo atribuído às amelogeninas em função da sua afinidade de ligação à superfície mineral do esmalte e a sua presença em maior quantidade em relação às enamelinas ${ }^{63}$. $O$ resultado de interferências nesse e em outros eventos ocorridos durante a amelogênese, se manifesta por meio dos distúrbios do desenvolvimento do esmalte, entre os quais destaca-se a fluorose dentária. 
A fluorose, entre os seres humanos, se estabeleceu a partir do uso indiscriminado do flúor* em suas várias formas de administração: os tabletes, geles, bochechos e dentifrícios, além da água de abastecimento público. Um uso que visava prevenir a cárie dentária, tornou os homens vulneráveis aos efeitos deletérios dos fluoretos**28.

Estabeleceram-se algumas hipóteses sobre a patogenia da fluorose, das quais foram propostos três mecanismos que poderiam alterar a produção, a degradação e a remoção das proteínas da matriz ${ }^{5,34}$. O primeiro diz respeito às perdas funcionais dos ameloblastos que afetariam diretamente suas propriedades de secreção e reabsorção21. Outro mecanismo está vinculado à inibição da atividade proteolítica das enzimas destinadas a degradação da matriz. O terceiro indica que o fluoreto incorporado à estrutura do cristal de apatita promove uma união mais estável entre a matriz inorgânica e a orgânica, tornando a clivagem das proteínas menos acessível, uma função executada pelas enzimas presentes no esmalte22.

\footnotetext{
Termo usado para definir a forma iônica, ionizável e não ionizável do elemento flúor. ${ }^{* *}$ Forma iônica e fisiologicamente ativa do flúor.
} 
Este trabalho, realizado com base nas hipóteses propostas para a patogenia da fluorose dentária, visa determinar e comparar a distribuição de amelogeninas na matriz orgânica de incisivos de ratos, afetada por exposição crônica ao fluoreto de sódio, bem como a densidade óptica da matriz do esmalte, a fim de se observar pelas técnicas imuno-histoquímica e H.E., o comprimento linear do componente orgânico do esmalte após o início do processo de mineralização do mesmo. 


\section{2 - REVIS ÃO DA LITERATURA}




\section{1 - A MATRIZ DO ESMALTE - Estrutura e Cinética}

O produto de secreção dos ameloblastos, as proteínas da matriz, tem sua história traçada desde o século XVIII pelo escocês JOHN HUNTER, um renomado membro do Royal College of Surgeons of England, que vislumbrava a natureza do esmalte e escreveu em seu livro The natural history of the human teeth: "Parecia ser barro unido a uma porção de substância animal". HUNTER acreditava que o esmalte possuía uma composição mucilagênica, uma vez que sob aquecimento, tornava-se quebradiço, enegrecido e separava-se da dentina25.

A natureza do esmalte mostra particularidades, quando comparada a outras estruturas mineralizadas estudadas. Atualmente, sabe-se que, ao completar a secreção, a matriz do esmalte deve apresentar em seu volume 50-60\% de água, 20-30\% de proteínas e 1520\% de mineral50. Esse percentual de proteínas desempenha funções 
cruciais, que permitem o correto desenvolvimento do esmalte. Conhecer as minúcias a respeito de sua estrutura e cinética inspirou diversas linhas de pesquisa. Algumas delas serão abordadas nessa revisão.

A primeira análise bioquímica completa quanto à composição de aminoácidos da matriz do esmalte foi realizada no ano de 1960 por PIEZ54. Removendo o conteúdo protéico de terceiros molares humanos, notou que não havia moléculas de hidroxiprolina e hidroxilisina em sua composição, mas apenas quantidades moderadas de glicina; evidenciando não se tratar de um tipo de colágeno. De acordo com o autor, sua composição não se parecia com a de nenhuma outra matriz protéica conhecida até então.

EASTOE26, em 1965, acrescentou informações interessantes aos achados de PIEZ, verificando que as proteínas do esmalte possuíam características singulares e distinguiam-se de outras proteínas, como o colágeno e a queratina. Sua singularidade se devia às porções altas de prolina, glutamina, histidina e leucina, encontradas em sua composição. A esse grupo de proteínas abundantes na fase de secreção 
da matriz do esmalte, deu-se pela primeira vez o nome de amelogeninas, designação pela qual são conhecidas atualmente.

A partir da premissa que "a estrutura determina a função"59, buscou-se o conhecimento acerca do arranjo primário ao quaternário das proteínas de matriz. A finalidade era elucidar, mesmo que parcialmente, suas funções. Desse modo, TRAVIS; GLIMCHER ${ }^{92}$, em 1964, sugeriram que as mesmas teriam um papel estrutural na qual, a matriz seria constituída de microcanais, demarcando a posição dos futuros cristais e prismas.

A estrutura quaternária das amelogeninas foi estudada em 1975 por SMALES75, que observou em incisivos de ratos a presença de estruturas globulares que pareciam arranjar-se de forma helicoidal em torno dos cristalitos formados, desempenhando provavelmente uma função especial na estruturação da fase mineral do esmalte. Suas hipóteses foram confirmadas com o passar dos anos, e dos experimentos.

Mesmo havendo algum consenso a respeito das particularidades encontradas nas proteínas do esmalte, pairavam 
dúvidas sobre a composição bioquímica, a dinâmica e as funções das mesmas. O experimento de SASAKI; SHIMOKAWA65, em 1979, buscava definir diferenças entre os possíveis grupos de proteínas por meio da eletroforese com gel de poliacrilamida, em extratos de órgãos do esmalte de incisivos bovinos. Observaram que a principal banda formada no gel possuía $25 \mathrm{kDa}$ e aparecia mais claramente no esmalte imaturo, diminuindo seu percentual com o avançar da mineralização. As isoformas com massas moleculares inferiores apareciam em maior número durante a maturação, sugerindo que as proteínas da banda de 25 kDa poderiam ser fragmentadas durante a amelogênese. Outra hipótese formulada referia-se a síntese de novo de pequenos grupos protéicos ao final do processo de formação do esmalte.

A primeira caracterização das moléculas de amelogeninas mostrou que se tratavam de produtos translacionais gerados por RNAm e que, em sua maioria, eram processados por proteinases específicas ${ }^{30}$. Estudando amelogeninas bovinas, FINCHAM et al. ${ }^{31}$, em 1981, identificaram dois peptídeos com cinco e seis $\mathrm{kDa}$, sendo que o primeiro pertencia à porção terminal amina da molécula nascente dessas proteínas. O peptídeo, contendo 44/45 resíduos de aminoácidos, foi denominado "proteína de amelogenina rica em 
tirosina" ou TRAP - tirosine rich amelogenin protein. O segundo não conseguiu ser relacionado a qualquer seqüência de amelogeninas bovinas estudadas.

Posteriormente, GIBSON et al35., em 1991, identificaram um polipeptídio com 59 resíduos de aminoácidos vindo de uma amelogenina praticamente idêntica à nascente, a não ser pela falta de um segmento em seu eixo central. Essa proteína, ao ser clivada e perder sua porção terminal carboxila, gerava o peptídeo em questão, que foi denominado LRAP - leucine rich amelogenin peptide. Notaram que havia uma transcrição alternativa de isoformas de amelogeninas. Dessa forma, eram gerados dois tipos de amelogeninas nascentes, uma produzindo o polipeptídeo TRAP e outra o LRAP, que subseqüentemente sofriam clivagens, formando outras isoformas menores. A reposta para o porquê de tantas isoformas e qual a sua importância funcional no contexto da amelogênese, ainda não foi totalmente esclarecido.

Conforme citam AOBA et al4., em 1992, as porções terminais das macromoléculas de amelogeninas mostraram-se extremamente conservadas em diferentes espécies, sugerindo uma significância 
funcional e evolutiva, relacionada à mineralização do esmalte na classe dos mamíferos. Os autores observaram ao estudar as amelogeninas suínas que, a capacidade de adsorção dessas proteínas sobre as moléculas de hidroxiapatita estava intimamente relacionada à sua estrutura. Ao perderem seu término carboxila, mostraram alta afinidade a hidroxiapatita. Utilizaram anti-soro dirigido à porção $C$ de amelogeninas de porcos e de outros mamíferos, a fim de caracterizar semelhanças estruturais e, por conseqüência, funcionais, entre as amelogeninas de suínos, bovinos, ratos e coelhos. Os resultados levaram os autores a concluir que, a porção terminal das amelogeninas, além de indicar preservação evolutiva, apresenta uma função determinante na capacidade de adsorção das mesmas sobre os cristais.

Buscando a expressão gênica das amelogeninas, SNEAD, em 198379 e 198580, seqüenciou e clonou o RNA mensageiro dessas proteínas, obtidas de germes dentários de camundongos. Sua contribuição permitiu que se aumentasse a especificidade na descrição e pesquisa sobre o grupo estudado de proteínas do esmalte. Os loci genéticos de amelogeninas humanas e murinas foram localizados nos cromossomos sexuais X por LAU et al ${ }^{44}$., em 1989. SALIDO et al64. e 
NAKAHORI et al49., em 1991, publicaram trabalhos diferentes abordando temas similares. Elucidaram ainda, a expressão de montantes genéticos de amelogeninas no cromossomo $\mathrm{Y}$; com a ressalva de haver quantidades menores de genes responsáveis por tais proteínas nesse alelo, cerca de $10 \%$ em relação ao X. Esses estudos com enfoque genético levaram à proposição de um possível dimorfismo sexual na espécie humana.

Em casos de amelogênese imperfeita, foram detectadas mutações no gene codificador de amelogeninas. Acredita-se que, a transcrição alternativa observada nas amelogeninas possa representar uma tentativa de salvaguarda do fenótipo frente às possíveis mutações. A aparência mais ou menos próxima a normalidade observada nos dentes de indivíduos afetados por essa doença seria talvez resultado da atuação do alelo no cromossomo $\mathrm{Y}$, ou ainda de outras proteínas do esmalte, não pertencentes ao grupo das amelogeninas 73 .

As propriedades físico-químicas das amelogeninas puderam ser analisadas minuciosamente com a realização de experimentos como os de SIMMER et al73., em 1994, que pretendiam obter uma fonte definida de amelogeninas a serem utilizadas como antígenos. Inseriram 
um gene codificador de amelogenina murina em E. coli, por meio de um vetor, para posterior produção de amelogeninas recombinantes. As E. coli, contendo o gene de camundongos, codificariam em si as amelogeninas desses roedores. As proteínas resultantes continham 179 resíduos, e as originais de camundongos 180 resíduos. A ME179, como foi designada, possui propriedades de ligação a hidroxiapatita e partilha similaridades funcionais com sua análoga de 180 resíduos de aminoácidos, presente no esmalte murino, e com a amelogenina de 173 resíduos, originária do esmalte dentário suíno.

A organização espacial das amelogeninas gerou questionamentos sobre como estas proteínas de matriz aparentemente aglomeradas poderiam formar um biomineral tão organizado. FINCHAM et al32., em 1995, procuraram elucidar a questão por meio do uso de uma amelogenina recombinante, produzida a partir de camundongos e denominada M179. Analisaram sua estrutura sob microscopia eletrônica de transmissão notaram áreas eletroluscentes arranjadas paralelamente aos cristalitos, com aproximadamente $20 \mathrm{~nm}$ de diâmetro. Sugeriram que a região terminal carboxila poderia se manter exposta sobre a superfície das amelogeninas organizadas em nanosferas, permitindo a formação de canais aniônicos, o que 
permitiria a essas estruturas um padrão de agrupamento ordenado. Esse seria um dos eventos responsáveis pela modulação da mineralização do esmalte, uma vez que as enzimas proteolíticas presentes na matriz poderiam atuar justamente sobre o término carboxila exposto, desorganizando as proteínas e proporcionando o crescimento dos cristais de hidroxiapatita.

Alguns modelos animais experimentais podem proporcionar uma boa caracterização da matriz orgânica do esmalte em desenvolvimento. HU et al38., em 1996, investigaram a expressão das isoformas de amelogeninas suínas. Das amelogeninas encontradas, prevaleceram as com 173 resíduos de aminoácidos, com 25kDa. Essa proteína nascente só pode ser observada nas camadas superficiais do esmalte devido à degradação que sofre logo após ser secretada. Ao perder parte de sua estrutura, próximo ao término carboxila, a amelogenina passa a possuir $23 \mathrm{kDa}$ de massa molecular e posteriormente peptídeos ainda menores, vindos de clivagens enzimáticas subseqüentes. Os autores afirmaram nesse trabalho, que essas características têm forte relação com o papel funcional das amelogeninas na amelogênese . 
Assim como a variedade de isoformas de amelogeninas denota funções a serem desempenhadas, sua distribuição espacial pode também sugerir sua atividade nas diferentes fases da amelogênese. Para demonstrar o padrão de distribuição de amelogeninas e comparálas com tuftelinas, DIEKWISK et al23., em 1997, marcaram por imunohistoquímica molares de camundongos em estádios intrauterinos e pós-natais. A distribuição de amelogeninas e tuftelinas, detectada nos resultados, apresentou variações. As tuftelinas foram identificadas entre os odontoblastos no início do período de secreção e com o avançar do processo migraram em direção à junção amelodentinária. As amelogeninas permeavam todo o esmalte, sendo que o produto de reação imuno-histoquímica mantinha intensidade homogênea. A partir dos dados obtidos, os autores sugeriram que, as tuftelinas poderiam ser secretadas pelos odontoblastos e penetrariam no esmalte, via prolongamentos, para dar suporte à nucleação de cristais. Uma sugestão alternativa seria a secreção das tuftelinas pelos ameloblastos, seguida de sua migração para a matriz dentinária. Nesse trabalho, as alterações espaciais e temporais na distribuição das proteínas de matriz estudadas, indicariam diferenças funcionais entre as mesmas. 
A solubilidade das amelogeninas foi associada à sua capacidade de agregação por TAN et al87., em 1998, que estudaram essa propriedade em um grupo de amelogeninas, utilizando uma isoforma recombinante de camundongos, denominada rM179, em soluções com diferente $\mathrm{pH}$ e frente aos íons divalentes $\mathrm{Ca}^{++}, \mathrm{Mg}^{++}$, $\mathrm{Zn}^{++}$. Observaram que, as amelogeninas eram insolúveis em $\mathrm{pH}$ fisiológico, provavelmente por tenderem a formar in vivo as estruturas quaternárias designadas nanosferas. Os autores sugeriram que as alterações cíclicas no $\mathrm{pH}$ do esmalte durante a amelogênese poderiam afetar o equilíbrio entre as amelogeninas e o fluido adamantino, alterando a sua estrutura quaternária, a sua associação com a fase mineral e sua susceptibilidade à proteólise. Tais mudanças na cinética de biomineralização do esmalte dentário, quando patológicas, promoveriam alterações estruturais e morfológicas em seu produto final.

Mesmo não havendo um total esclarecimento acerca das particularidades estruturais e funcionais das proteínas do esmalte, os estudos realizados acrescentaram valiosos dados ao conhecimento das patologias relacionadas ao desenvolvimento de um biomineral tão 
interessante como o esmalte. A esse grupo de doenças dá-se o nome de distúrbios do desenvolvimento do esmalte.

\section{2 - OS DISTÚRBIOS DO DESENVOLVIMENTO DO ESMALTE -}

Nos distúrbios do desenvolvimento do esmalte encontram-se classificadas as hipoplasias que abrangem o grupo das hipomineralizações. O termo hipoplasia costuma ser usado quando há formação incorreta dessa estrutura; aplica-se às alterações na produção e secreção do componente orgânico do esmalte, resultando em perdas quantitativas 85 .

A hipomineralização caracteriza-se por distúrbios em que, o esmalte não se apresenta inteiramente mineralizado, mesmo mantendo sua espessura padrão48. Ocorrem desajustes funcionais, principalmente no período que corresponde à maturação do esmalte, alterando suas características físicas finais. Macroscopicamente, a hipomineralização pode não ser tão detectável como usualmente ocorre com as hipoplasias 82. 
A etiologia das hipoplasias pode ser local, geralmente causada por traumas e infecções, ou sistêmica abrangendo numerosos fatores. Esses tipos de distúrbios do desenvolvimento do esmalte podem ser reproduzidos experimentalmente. TANIGUCHI, et al88., em 1999, aplicou forças traumáticas intrusivas em germes de molares de ratos. Observaram hipoplasias delimitadas nos germes dos animais com um e com dez dias de idade; períodos relativos ao início da formação da matriz do esmalte e à sua mineralização. Nos períodos correspondentes ao aumento volumétrico da matriz (três, cinco e sete dias pós-natais), as lesões pareceram mais intensas e difusas, refletindo uma desorganização estrutural na formação do esmalte. Os autores propuseram o modelo experimental utilizado como uma metodologia adequada para o estudo da histogênese das hipoplasias do esmalte geradas a partir de traumas.

As anomalias cromossômicas, como a trissomia do 21; as deformidades craniofaciais e os distúrbios metabólicos congênitos, como a fenilcetonúria e a porfiria eritropoiética, podem ser observados no estudo das etiologias sistêmicas dos distúrbios do desenvolvimento do esmalte. PINDBORG55, em 1982, revisou grande parte desses distúrbios, incluindo as doenças determinadas citogeneticamente e as 
relacionadas aos padrões monogênicos de hereditariedade, como a amelogênese imperfeita que pode ocorrer isoladamente ou associada a outras doenças. Entre elas a epidermólise bolhosa, o pseudohipoparatireoidismo ou a Síndrome tricodentoóssea. Na amelogênese imperfeita, o esmalte dentário pode apresentar-se hipoplásico ou hipomineralizado. Essas características estão relacionadas aos genes codificadores de amelogeninas com defeitos herdados pelos cromossomos sexuais. Esse é o padrão de hereditariedade que tem sido mais estudado na amelogênese imperfeita, porém existem expressões da doença, transmitidas de forma autossômica, como aquelas envolvendo loci gênicos presentes no cromossomo quatro 43 .

Alguns tipos de drogas e outros compostos químicos estão relacionadas a formação de distúrbios do desenvolvimento do esmalte, tanto no período neonatal (até o primeiro mês de vida), quanto nos primeiros meses e anos de vida das crianças. Um exemplo citado e estudado é a talidomida, que tem capacidade antiemética em gestantes, no entanto sua ingestão durante esse período gera severas más-formações fetais. AXRUP et al7., em 1966, que constataram 49\% de hipoplasias nos decíduos de crianças com embriopatias causadas pela talidomida. 
Muitos fatores de envolvimento sistêmico podem atuar em períodos de tempo limitados ou não, produzindo áreas identificáveis clinicamente no padrão incremental de deposição do esmalte. A superfície do esmalte passa a exibir alterações variáveis de acordo com a severidade e a natureza dos fatores causais dos distúrbios do desenvolvimento ${ }^{48}$. A odontodisplasia regional pode ser citada como um dos exemplos extremos de disgenesias dentárias, cujos fatores circulatórios locais levam a uma perda na estruturação de todo o dente, que assume, radiograficamente, um aspecto translúcido e recebe o nome de "dente fantasma". A análise subcelular desses dentes mostra padrões de mineralização patológicos na estrutura prismática do esmalte, com o tamanho e a forma dos cristalitos alterados, bem como a proporção desajustada de elementos como $\mathrm{Mg}^{++} / \mathrm{Ca}^{++}$e $\mathrm{Na}^{+} / \mathrm{Ca}^{++} 63$.

Baseando-se nos critérios macroscópicos dos distúrbios do desenvolvimento do esmalte, foram determinadas três categorias de distúrbios: as hipoplasias, as opacidades delimitadas e as difusas. O primeiro índice DDE (Developmental Disturbances of Enamel) foi apresentado ao FDA (Food and Drug Administration). Modificações para a classificação original foram publicadas em 199215 (Tabela 1), omitindo-se a classe das alterações de cor ${ }^{84}$. A tetraciclina costuma ser 
a responsável com grande freqüência por essas alterações na cor de dentes decíduos e permanentes; um efeito que aparece como resultado da incorporação da droga durante a formação das estruturas mineralizadas dos dentes 55 .

Tabela 1 - Índice DDE modificado, usado para estudos epidemiológicos

\begin{tabular}{|c|c|}
\hline TIPO DE DISTÚRBIO & CÓDIGO \\
\hline Esmalte Normal & 0 \\
\hline \multicolumn{2}{|l|}{ Opacidades Demarcadas } \\
\hline Brancas/Beges & 1 \\
\hline Amarelas/Castanhas & 2 \\
\hline \multicolumn{2}{|l|}{ Opacidades Difusas } \\
\hline Lineares & 3 \\
\hline Maculares & 4 \\
\hline Confluentes & 5 \\
\hline Máculas confluentes + Pigmentações + Perda de esmalte & 6 \\
\hline \multicolumn{2}{|l|}{ Hipoplasias } \\
\hline Pontos & 7 \\
\hline Perda de esmalte & 8 \\
\hline Outros distúrbios & 9 \\
\hline \multicolumn{2}{|l|}{ Combinações } \\
\hline Demarcados e Difusas & A \\
\hline Demarcadas e Hipoplasias & B \\
\hline Difusas e Hipoplasias & $\mathrm{C}$ \\
\hline Todos os três distúrbios & $\mathrm{D}$ \\
\hline
\end{tabular}


As classificações macroscópicas dos distúrbios do desenvolvimento do esmalte são de grande utilidade na prática clínica e nos levantamentos epidemiológicos, mas as respostas para a patogenia de boa parte desses distúrbios encontram-se implícitas no detalhamento das fases da amelogênese, da composição física e bioquímica do esmalte; o que justifica serem esses focos freqüentes de atenção e pesquisa.

O padrão progressivo de formação do esmalte em germes de molares de cabras e ovelhas, foi estudado por SUGA81 em 1982, que utilizou radiomicrografias para comparar seus resultados com os de estudos prévios em outros mamíferos. Observou que, entre os fatores que atuam sobre o processo de mineralização estão a composição química e física da matriz orgânica e o movimento de íons e substâncias orgânicas por meio das células do órgão do esmalte e dos túbulos dentinários. Possivelmente, os ameloblastos ao serem atingidos por compostos tais quais o fluoreto de sódio, e desorganizados durante o final do estádio de secreção e o início da maturação, originariam a perda da continuidade da mineralização na área subjacente. As alterações na forma e no gradiente de mineralização ocorridas nos 
espécimes estudados deviam-se, entre outros fatores, às diferenças na composição química de cada camada depositada.

A desorganização do processo de maturação induzida por alterações citológicas nos ameloblastos, como resultado da interferência de fatores externos, foi avaliada em 1987, por SUGA et al83. Utilizaram radiomicrografias e cortes para microscopia óptica de dentes de ratos, apresentando distúrbios do desenvolvimento causados pela administração de fluoreto de sódio e estrôncio na água de consumo. O fluoreto de sódio foi acrescido à água nas concentrações de 100, 200 e 300ppm, durante 40 dias. Cinco horas antes do sacrifício dos grupos, os animais receberam injeção de tetracloreto de tetraciclina a $6 \mathrm{mg} / 100 \mathrm{mg}$ de peso. A droga foi injetada para demarcar as áreas de mineralização sem alterações em sua formação. Foram realizadas ainda, análises dos elementos $\mathrm{Ca}, \mathrm{P}, \mathrm{Mg}$, Fe, além do Sr e do F. Notou-se que, na hipomineralização causada pelo fluoreto de sódio e pelo estrôncio, o ferro penetrou profundamente no esmalte, algumas vezes alcançando a junção amelodentinária, presumivelmente devido à alta porosidade da matriz. Constataram que, a formação da matriz do esmalte atravessa diferentes subfases, e que os compostos testados 
influenciam os mecanismos envolvidos na amelogênese, podendo configurar-se em um processo com padrões e proporções distorcidas.

Ainda estudando os eventos característicos da mineralização, SUGA 82,1989 , enfatizou a importância do equilíbrio temporal e espacial no momento da formação seqüencial das várias camadas do esmalte. Notou que a camada externa manteve um grau relativamente baixo de mineralização no início da maturação, aumentando rapidamente e atingindo seu nível máximo ao término da mesma. Sugeriu que a subsuperfície do esmalte permaneceria menos mineralizada, provavelmente com a função de permitir o transporte de agentes envolvidos no processo. Ao final da maturação, a distribuição de elementos como o flúor, o zinco, o magnésio e o sódio, poderia propiciar a mineralização acelerada dessa delgada camada logo abaixo da superfície. A precocidade ou concentração elevada de alguns compostos envolvidos na mineralização, como o flúor, poderia levar à maturação incompleta do esmalte, particularmente na camada subjacente à superfície.

A relação entre as alterações ocorridas durante a amelogênese e o mecanismo de ação do flúor parece conter em si boa parte das 
respostas referentes à produção da fluorose dentária, um dos mais freqüentes distúrbios do desenvolvimento do esmalte observado na espécie humana.

\section{3 - A FLUOROSE DENTÁRIA -}

Nos animais, principalmente em humanos e mamíferos herbívoros, observa-se uma alta incidência de fluorose. Entre outros fatores, esse distúrbio tem relação direta com o consumo de vegetais no caso dos herbívoros, e com a água. O fato foi observado em regiões da terra onde havia alta concentração de flúor no solo, por SHUPE70, em 1971.

Entre os aspectos inerentes à patogenia da fluorose, demonstrou-se uma diminuição na porção inorgânica do esmalte de humanos 10 e de ratos 68 . Em pesquisas com animais experimentais, a severidade das lesões causadas pelo flúor foi associada à duração, ao modo de administração e a concentração empregada nas doses de fluoreto. 
FEJERSKOV; YAEGER; THYLSTRUP27, em 1979, produziram fluorose, em incisivos de ratos, ao acrescentar em sua água de consumo diário $100 \mathrm{ppm}$ de fluoreto de sódio. Notaram ainda que, a concentração referida não foi suficiente para produzir um esmalte hipoplásico. Concluíram que, no modelo de estudo utilizado, o grau de comprometimento do esmalte seria dependente da dose de flúor administrada. O autor considerou que, as diferenças evolutivas entre os humanos $\mathrm{e}$ os pequenos roedores seriam superadas pela similaridade das características básicas encontradas em seus dentes, não desabonando portanto a comparação entre ambos.

Para que as lesões produzidas em animais pudessem mimetizar as humanas, as doses de flúor ingeridas deveriam ser proporcionalmente similares. Desse modo, estimou-se que 100ppm de fluoreto de sódio na água de consumo diário, produziria em ratos uma concentração de flúor entre 12 e 13 mg/kg de massa corporal58,27.

As diferenças entre espécies não invalidam os resultados experimentais, principalmente se tais diferenças forem previsíveis e mensuráveis. Entre ratos e homens, o índice metabólico dos dentes é obviamente incompatível, daí a necessidade de doses bem mais altas 
para que haja distúrbios nos dentes de roedores. Um parâmetro que pode ser quantificado e correlacionado ao grau de agressão ocasionado pelo flúor, em qualquer espécie estudada, é a concentração desse composto no plasma58.

Os níveis plasmáticos de flúor, bem como a massa corporal, o crescimento esquelético e os períodos de remodelação óssea, são fatores metabólicos que podem influenciar o desencadeamento da fluorose dentária18. O transporte e a absorção do flúor, de onde quer que seja mobilizado, ocorrem rapidamente e ainda que essa absorção seja regulada pela camada papilar do esmalte ${ }^{8}$ de incisivos de ratos, a desorganização estrutural do mesmo acaba sendo inevitável.

SINGER; ARMSTRONG 74 , em 1961, correlacionaram a ocorrência de alterações na mineralização do esmalte com elevados níveis de flúor no sangue. ANGMAR-MÅNSSON; WHITFORD ${ }^{1}$ observaram, em 1985, que doses agudas de fluoreto de sódio injetadas em ratos poderiam acarretar fluorose no esmalte subseqüentemente irrompido, mesmo após os índices altos de flúor plasmático terem retornado aos níveis basais. Propuseram que esse composto poderia ser mobilizado do osso adjacente para o órgão do esmalte ${ }^{2}$. 0 
experimento de BRÓGLIO'11, em 1994, constatou que, ratos submetidos a doses únicas de fluoretos, mesmo após 16 dias continham concentrações sangüíneas que poderiam ser relacionadas a defeitos na amelogênese e que, a liberação de flúor pelo osso adjacente ao órgão do esmalte também agravaria as alterações decorrentes da fluorose.

Acreditando que, a interferência do flúor poderia alterar não só a mineralização, bem como a diferenciação dos ameloblastos e a modulação do processo de síntese e secreção da matriz do esmalte, as pesquisas realizadas nessa área procuraram determinar quais mudanças ocorreriam em cada uma das etapas da amelogênese 5,13,19,20. As fases da amelogênese recebem pequenas variações em sua classificação devido aos critérios adotados por cada autor, nessa revisão serão consideradas as fases, pré-secretora, secretora, de transição e maturação.

KRUGER ${ }^{40}$, em 1970, induziu fluorose dentária em ratos, por meio de injeções intraperitoniais de fluoreto de sódio nas concentrações de sete, três e $0,1 \mathrm{mg} \mathrm{F} / \mathrm{kg}$. A partir da análise das alterações na ultraestrutura dos ameloblastos, considerou a dose de 0,1 mg f/kg de massa corporal, a dose limítrofe na promoção de 
fluorose, no modelo experimental utilizado; sendo essa quantidade consideravelmente mais alta que os $0,04 \mathrm{mg} \mathrm{F} / \mathrm{kg}$ capazes de causar fluorose em humanos. A dose mínima utilizada no experimento foi capaz de causar alterações compatíveis com fluorose dentária, porém não provocou alterações ultraestruturais nos ameloblastos.

Em 1972, o mesmo autor ${ }^{41}$ acreditando que a síntese e secreção de proteínas poderiam sofrer modificações perante compostos fluoretados, injetou em ratos fluoreto de sódio a três, 0,05 e 0,01 mg F/ $\mathrm{kg}$ e estudou a incorporação de serina à matriz do esmalte. O fosfato de serina, conforme KRUGER, foi identificado na matriz do esmalte bovino e, teoricamente, teria influência no crescimento dos cristais de apatita. Na análise dos seus resultados notou que, após uma hora houve diminuição na entrada de serina na matriz, quando a dose foi de três $\mathrm{mg} \mathrm{F} / \mathrm{kg}$ e que, as duas outras doses foram insuficientes para alterar a incorporação do aminoácido. Sugeriu que os eventos bioquímicos observados poderiam estar envolvidos na queda de síntese e secreção protéica, necessária para produção da matriz extracelular.

A citotoxicidade do flúor nas células do epitélio interno do órgão do esmalte, precursoras dos ameloblastos, foi testada por 
BRONKERS; JENSEN; WOLTGENS13, em 1984. Usaram, segundos molares de hamsters (Mesocricetus auratus L) com três e quatro dias de idade, período correspondente ao final da secreção da matriz. Com os germes dentários, realizaram cultura de células, expondo-as por oito dias ao flúor em forma de NaF. Adotaram concentrações que variaram de $2,6 \mu \mathrm{M} / \mathrm{L}(=0,05 \mathrm{ppm})$ a $1,31 \mathrm{mM} / \mathrm{L} \quad(=25 \mathrm{ppm})$. Os resultados indicaram que, nas culturas de células com $1,31 \mathrm{mM} / \mathrm{L}$, não houve praticamente a produção de esmalte e os ameloblastos pareciam desorganizados e tendiam a tornar-se morfologicamente alterados. Com $52 \mu \mathrm{M} / \mathrm{L}(=1 \mathrm{ppm})$ a matriz produzida mostrava-se amorfa e com $26 \mu \mathrm{M} / \mathrm{L}(=0,5 \mathrm{ppm})$ havia a presença de uma matriz do esmalte dentro

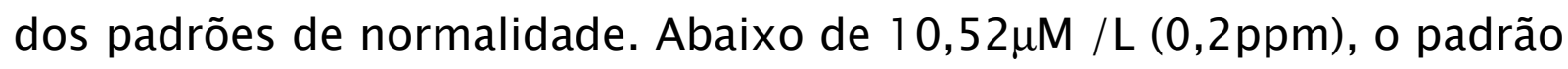
morfológico da matriz produzida foi o mesmo que o do grupo controle. Concluíram que, a quantidade mínima de flúor que afeta o desenvolvimento do esmalte dentário de hamsters em cultura de células, foi de $1,31 \mathrm{mM}$ ou $1315 \mu \mathrm{M} / \mathrm{L}$, equivalente a $25 \mathrm{ppm}$ de fluoreto de sódio.

A diminuição do montante de proteínas do esmalte, secretadas em dentes com fluorose, foi um dos aspectos estudados por DENBESTEN; CRENSHAW20, em 1984. Ao compararem quantitativamente 
a matriz do estádio secretor nos dentes com e sem fluorose, não observaram diferenças entre os grupos, quanto à quantidade de proteínas. O efeito da ingestão crônica de doses altas de flúor sobre a maturação do esmalte também foi testado nesse mesmo experimento. Usaram ratos como modelo experimental oferecendo-lhes, na água de consumo, fluoreto em concentrações de 75, 100 e 150ppm. Após cinco semanas, compararam os grupos com base nos componentes protéicos e na presença flúor. Os resultados indicaram que, a partir de $75 \mathrm{ppm}$ houve aumento na concentração de flúor e retenção das proteínas de matriz, levando-os a sugerir uma provável interferência no desenvolvimento pós-secretor e pré-eruptivo do esmalte dos espécimes estudados. Em 198521, utilizando uma metodologia similar, notaram que, no início da maturação a ingestão crônica de $75 p p m$ de flúor era suficiente para quebrar a modulação dos ameloblastos, um outro fator que poderia contribuir para a retenção das proteínas.

Em 1986, DENBESTEN17 avaliou novamente os efeitos do flúor em cada um dos estádios de formação do esmalte, usando a cromatografia e a eletroforese em espécimes obtidos de ratos, submetidos a doses de 10, 25, 50 e 100ppm de fluoreto de sódio. Com a eletroforese observaram que, em todas as isoformas estudadas houve 
um atraso na clivagem enzimática durante a maturação, mesmo tendo sido quase todas removidas ao final desse período, atribuindo ao flúor um efeito direto na atividade enzimática e conseqüentemente no atraso da remoção das proteínas do esmalte .

A falta de remoção das proteínas do esmalte pode ser considerada como a responsável pela diminuição na quantidade e no índice de nucleação dos cristais de apatita do esmalte ${ }^{4}$. Essa hipótese foi demonstrada por AOBA et $a^{3}$., em 1987, que observaram in vitro o potencial de inibição de crescimento cristalino exercido pelas proteínas do esmalte. Uma interferência na degradação dessas proteínas poderia estar associada à permanência prolongada das mesmas e, conseqüentemente, a deficiência de mineralização. Os dentes afetados pela fluorose mostram esse padrão de alteração62.

O início do estádio de maturação parece apresentar uma susceptibilidade maior aos efeitos negativos do flúor, que poderia gerar inibição da proteólise na matriz, resultando no acúmulo de material orgânico. Os achados de LYARUU et al47., em 1987, indicaram que a matriz sintetizada e secretada na presença de $10 \mathrm{mg} \mathrm{F} / \mathrm{ml}$ de água destilada, em cultura de germes dentários de hamsters, mantém sua 
capacidade de sustentar o crescimento cristalino quando o flúor é removido da cultura. Mesmo não se conhecendo com exatidão a função das amelogeninas na mineralização do esmalte, acredita-se que as mesmas controlam a orientação do crescimento dos cristais em extensão. A administração do flúor, in vitro, durante a fase secretora da amelogênese inibe tal crescimento, indicando que o flúor rompe temporariamente o controle das amelogeninas sobre a mineralização 47.

As efetoras da degradação enzimática foram identificadas 80 como produtos de secreção dos ameloblastos, divididos em dois grupos: as proteases serinas e as metaloproteinases. Permeando a fase fluida do esmalte, atuariam na matriz clivando o término carboxila de algumas proteínas recém-secretadas e alterando a sua massa molecular. Outra função desempenhada pelos grupos de enzimas proteolíticas do esmalte, estaria relacionada à degradação e remoção das proteínas, permitindo que a disponibilidade de áreas livres para o crescimento dos cristalitos de hidroxiapatita $5,30$.

Acredita-se que, o influxo de íons flúor poderia interferir indiretamente na atuação das proteases sobre as proteínas do esmalte, principalmente as amelogeninas. OVERALL; LIMEBACK ${ }^{53}$, em 1988, 
sugeriram que a serina denominada amelogeninase seria ativada por uma metaloproteinase e que, para tal ativação a mediação do $\mathrm{Ca}^{++}$se fazia necessária, porém o flúor poderia interferir na atuação dos íons cálcio sobre essas enzimas, resultando em um distúrbio funcional por parte das mesmas e na retenção das amelogeninas.

TANABE et al86., 1988, estudaram a interação das amelogeninas com a superfície dos cristais de apatita, utilizando em sua metodologia germes de incisivos permanentes de suínos, enfatizando a substituição isomórfica do radical hidroxila pelo fluoreto na superfície cristalina. Demonstraram que a substituição da hidroxila por fluoreto nos cristais de apatita pode elevar a adsorção das proteínas do esmalte por aumentar, no meio, o número de moléculas com capacidade de adsorção, o que pode ser explicado pela alta estabilidade da superfície de fluorapatita, implicando em uma menor liberação de energia e na interação mais frágil entre a superfície e as moléculas de água. De acordo com os autores, como a fluorapatita desloca mais água que a hidroxiapatita, as moléculas hidrofílicas de amelogeninas teriam sua interação com essa superfície aumentada. Esses eventos poderiam afetar a degradação enzimática das 
amelogeninas devido à atividade catalítica da superfície do esmalte em formação ou pela modulação da conformação do substrato em questão.

Ainda em relação às interações bioquímicas ocorridas na estrutura do esmalte, buscou-se determinar a possível capacidade de ligação do flúor as proteínas de matriz. Para tanto, DENBESTEN et al22., em 1992, utilizaram 26 ratos, com água contendo zero e 100ppm de fluoreto de sódio, ad libitum, por seis semanas. Após a realização de seu experimento, constataram existência de ligação iônica entre flúor e as proteínas das matrizes em mineralização estudadas. Observaram ainda uma interação entre o cálcio e o flúor durante a fase secretora e sugeriram que o composto formado poderia afetar a remoção das proteínas e, conseqüentemente, a maturação do esmalte.

A demonstração morfológica da alteração na maturação do esmalte por atraso na remoção da matriz protéica, foi abordada por ZHOU et al95., em 1996, que a fizeram por meio de avaliações morfométricas e auto-radiográficas, em incisivos de ratos expostos, de forma crônica, a doses de 75 e 100ppm de fluoreto de sódio, no período de seis semanas. Ao mensurarem o comprimento da matriz na região pós-secretora, observaram que seu comprimento era maior nos grupos com fluorose em relação ao controle, o que seria uma 
confirmação morfológica do atraso da degradação e reabsorção das proteínas de matriz, causando hipomineralização.

Explicar o atraso da degradação da matriz do esmalte, tem sido um dos aspectos mais estudados em relação à patogenia da fluorose dentária. Uma das respostas para esse processo está na possível ação direta do flúor sobre a atividade das enzimas proteolíticas, destinadas a clivar as proteínas do esmalte ${ }^{17}$. GERLACH et al34., 2000, comprovaram, utilizando colorimetria e zimografia em matriz de esmalte extraída de ratos, não haver efeito direto do flúor livre sobre as proteinases. Conforme os autores, seus resultados permitiram a exclusão dessa hipótese para o desenvolvimento da fluorose, sendo consideradas mais viáveis, as prováveis trocas energéticas na superfície dos cristais frente ao flúor.

De qualquer modo, as hipóteses relacionadas ao comportamento da matriz protéica do esmalte frente ao excesso de flúor voltam-se à permanência das amelogeninas nessa matriz, que se torna deficiente em mineralização e produz um esmalte estruturalmente deficiente. A identificação específica das amelogeninas, a verificação do seu padrão de distribuição no decorrer da 
amelogênese, bem como sua análise quantitativa, podem contribuir para a busca de respostas específicas sobre a fluorose. 
3 - PROPOSIÇÃO 


\section{3 - Proposição}

Diante do interesse em caracterizar a fluorose dentária, conforme seus parâmetros morfológicos, este trabalho visou:

1. Descrever o padrão de distribuição das amelogeninas por meio de técnica imunohistoquímica.

2. Determinar, por meio de morfometria, o comprimento linear da matriz do esmalte.

3. Analisar a densidade óptica ao longo da matriz do esmalte em maturação, corada por hematoxilina e eosina. 
4 - MATERIAL E MÉTODOS 


\section{4 - Material e Métodos}

\section{1 - SELEÇÃO DOS ANIMAIS}

Foram utilizados 15 ratos (Rattus novergicus) da linhagem Wistar, obtidos do Biotério Central da Faculdade de Odontologia de Bauru, USP, e alojados em três caixas de poliestireno, em grupos de cinco, durante o período experimental de 42 dias. Os animais, do gênero feminino, com massa corporal estimada em $35 \mathrm{~g}$ e 23 dias de vida*, foram divididos em três grupos:

\section{Grupo experimental I (GI)}

Grupo experimental II (GII)

Grupo controle (GIII)

* Dois dias após terem sido desmamados 


\section{2 - OBTENÇÃO DOS ESPÉCIMES}

\subsubsection{Grupo experimental I}

Dosagem tóxica: Durante seis semanas, cinco ratos receberam água deionizada contendo $100 \mathrm{ppm}$ de flúor $(221 \mathrm{mg}$ fluoreto de sódio/L), preparado no Departamento de Bioquímica da Faculdade de Odontologia de Bauru - USP e ração Labina (Purina). A ração foi oferecida aos três grupos e a quantidade consumida não foi mensurada. A quantidade de água consumida foi quantificada a cada dois ou três dias e a massa dos animais, aferida semanalmente 77 .

\subsubsection{Grupo experimental II}

Dosagem compatível com a água potável consumida por humanos - 0,7ppm. Durante o mesmo período, cinco ratos receberam água deionizada com 7ppm de flúor. 


\subsubsection{Grupo controle}

Constou desse grupo a mesma quantidade de animais dos anteriores, sendo-Ihes oferecido, durante o mesmo período, apenas água deionizada.

Ao término do período experimental de 42 dias, os animais foram pré-anestesiados com éter etílico p.a. e anestesiados com injeção intraperitonial de miorrelaxante Rompun (xilazina - Bayer) na dosagem de $5 \mathrm{mg} / \mathrm{kg}$. Foi associada à primeira droga $50 \mathrm{mg} / \mathrm{kg}$ de anestésico Ketamin (cloridrato de cetamina - Cristália), resultando na proporção total de $55 \mathrm{mg} / \mathrm{kg}$ de massa corporal 16 . O ventrículo esquerdo de cada animal foi puncionado, o átrio direito incisionado e, em seguida, foram injetados respectivamente $\mathrm{NaCl}$ a $0,9 \%$ e solução fixadora. A solução fixadora foi preparada com paraformaldeído a $4 \%$ e glutaraldeído a $1 \%$, em solução de fosfato de sódio tamponado em $\mathrm{pH}$ 7.424. As perfusões foram consideradas satisfatórias quando, após 10 a 15 minutos da injeção da solução fixadora, podia-se observar o enrijecimento de todos os órgãos do animal. 
As mandíbulas dissecadas foram mantidas em fixador por 48 horas e posteriormente desmineralizadas com EDTA (ácido etilenodiamino tetracético dissódico) a $4.13 \%$ em pH 7.4 , a $4^{\circ} \mathrm{C}$, durante quatro semanas ${ }^{94}$. O tecido mole foi removido, o remanescente mineralizado, lavado em fosfato de sódio tamponado em $\mathrm{pH} 7.4$, e seccionado paralelamente ao longo eixo dos incisivos inferiores.

\section{3 - PROCESSAMENTO HISTOTÉCNICO}

As 15 mandíbulas foram divididas em 30 hemimandíbulas que receberam procedimentos padronizados de desidratação em etanol, diafanização em xilol e inclusão em parafina, com a face de corte no sentido longitudinal. Os cortes de $5 \mu \mathrm{m}$ de espessura foram obtidos no micrótomo rotativo Jung RM 2045-Leica. Foi montado um corte em cada lâmina de vidro. A coloração foi feita em 15 hemimandíbulas com H.E. (Hematoxilina Eosina) e nas outras 15 pela técnica imunohistoquímica, selecionadas aleatoriamente por animal dentro dos três grupos estudados. Para esta última técnica, descrita no item quatro, as lâminas receberam previamente uma película do adesivo ymethacryloxypropyltrimethoxysilane

(Sigma)

Foram

feitos 
aproximadamente cinco cortes em cada espécime, perfazendo um total de 150 lâminas. Os cortes foram analisados em fotomicroscópio Olympus $\mathrm{CH}-2$, do Departamento de Morfologia da Faculdade de Odontologia de Bauru, USP.

\section{4 - IMUNO-HISTOQUÍMICA}

\subsubsection{Material utilizado}

Os anticorpos policlonais primários, dirigidos contra a forma recombinante amelogenina suína, foram gentilmente cedidos pelo Dr. James P. Simmer, do Departamento de Odontologia Pediátrica, Escola de Odontologia, do Centro de Ciência e Saúde da Universidade do Texas em San Antonio, Texas, USA. As amelogeninas recombinantes foram preparadas a partir de E. coli transgênicas 73 .

A partir das recomendações enviadas com os anticorpos liofilizados, foram reconstituídos em $100 \mu \mathrm{l}$ de água destilada e diluídos na razão de 1:3000 em PBS com BSA a 1\%. Os dois tubos recebidos continham o soro obtido do segundo sangramento de coelho e o mesmo absorvido com extrato de E. coli, com a finalidade de evitar 
reações cruzadas com proteínas da própria E. coli. A proteína utilizada como antígeno diferencia-se de sua isoforma in vivo (com 173 aminoácidos) por perder uma metionina no término $\mathrm{N}$, contendo apenas 172 resíduos de aminoácidos ${ }^{\star}$.

O processamento imuno-histoquímico se deu conforme instruções do fabricante do kit DAKO LSAB2, selecionado e adquirido com a intenção de permitir uma boa reatividade com o anticorpo primário. Os reagentes secundários escolhidos foram os seguintes :

$>$ Kit DAKO LSAB 2, Fosfatase Alcalina para uso em espécimes de rato (DAKO LSAB2 Kit, AP, Rat. DAKO A/S)

$>$ Sistema de substrato cromogênico New Fuccin (Dako A/S)

\subsubsection{Padronização da técnica}

4.4.2.1. Desparafinização e reidratação

Cortes de $5 \mu \mathrm{m}$

Lâminas silanizadas

* Comunicação pessoal - James P. Simmer 
Cortar e deixar a $37^{\circ} \mathrm{C}$ por toda noite

Transferir para estufa $-56^{\circ} \mathrm{C}$ a $60^{\circ} \mathrm{C}$

Xilol $1-15$

Xilol 2 - 15

Álcool absoluto 1 - 5'

Álcool absoluto 2 - 5'

Álcool 95\% - 5'

Lavar em água destilada - 5'

4.4.2.2. Digestão enzimática

Tripsina (Sigma) a 0.25\% (diluída em PBS)

Deixar por 30' em temperatura ambiente

Lavar em PBS - 5'

Lavar em água destilada

4.4.2.3. Inativação da fosfatase alcalina endógena Ácido acético a $20 \%$, por 15 segundos a $4{ }^{\circ} \mathrm{C}$ Lavar em PBS - três vezes

4.4.2.4. Anticorpo primário 
Anticorpo para amelogenina recombinante de porco, absorvido com extrato de E. coli.

Secar o excesso ao redor do corte

Diluir 1:3000 do anticorpo, já reconstituído, em solução contendo BSA 1\% em PBS.

Incubar por 24 horas

Lavar em PBS - 5'

4.4.2.5. Link - Anticorpo secundário biotinilado (DAKO LSAB2/ rat)

Secar o excesso ao redor do corte

Incubar por 30'

Lavar em PBS - 5'

4.4.2.6. Fosfatase alcalina / Streptavidina (DAKO LSAB2 / rat)

Secar o excesso

Incubar por 30'

Lavar em PBS - 5'

4.4.2.7. Substrato cromogênico

Secar o excesso

Incubar por 10'

Lavar em água destilada 
4.4.2.8. Contracoloração

Verde de metila

Aplicar a solução por 20 " sobre os cortes previamente secos por exposição ao meio ambiente

Lavar com água destilada

Deixar secar

4.4.2.9. Montagem

Manter as lâminas previamente desidratadas, por exposição ao meio ambiente, em xilol por 15"

Cobrir as lâminas com meio de montagem Permount Montar as lâminas com lamínulas

\section{5 - ANÁLISE MORFOLÓGICA DESCRITIVA}

A análise descritiva foi realizada em 75 cortes microscópicos processados para a coloração imuno-histoquímica e examinados no microscópio de luz Olympus CH-2. 


\section{6 - ANÁLISE QUANTITATIVA}

Para a análise quantitativa priorizou-se a utilização do Sistema Analisador de Imagens Kontron KS300 (Kontron Eletronic GMBM). O procedimento teve início com a captura das imagens dos cortes microscópicos por uma câmera CCD - Iris RGB - Sony, instalada em um microscópio Zeiss Axioskop2 Trinocular. As imagens obtidas por meio de objetiva 10x, foram transmitidas a um computador IBM.

\subsubsection{Comprimento Linear da Matriz do Esmalte}

Foram selecionados cortes microscópicos marcados pela imunohistoquímica para a aplicação dessa técnica. As medidas do comprimento total da matriz foram determinadas pela distância linear entre os seguintes pontos: o primeiro marcado no início da matriz produzida na região apical e outro no final da matriz íntegra vista na zona de maturação remanescente. As medidas obtidas em pixels foram convertidas imediatamente em micrometros pelo analisador, calibrado previamente para o aumento eleito para esse tipo de análise. 
Para a mensuração da matriz do esmalte em maturação foram utilizados cortes corados por H.E., sendo os mesmos onde se realizaram as análises de densitometria. O ponto inicial foi marcado na zona determinada morfologicamente como de transição e o segundo ponto correspondeu ao final da matriz íntegra, observada na zona de maturação.

\subsubsection{Densidade da Matriz do Esmalte}

As mesmas imagens da matriz do esmalte capturadas para determinar o comprimento da matriz na fase inicial de maturação foram avaliadas pelo programa de densitometria contido no sistema Analisador de Imagens KS 300 Kontron KS300 (Kontron Eletronic GMBM) que, converte a cor original em tons de cinza e expressa o valor em unidades denominadas gray, de acordo com a densidade da estrutura que se está avaliando. Esses tons ou unidades variam de 0 a 255, ou seja, do transparente ao opaco. Na utilização de coloração de rotina (H.E.), a afinidade tintorial de um corte para outro pode sofrer pequenas variações, mesmo dentro de um só grupo. A primeira avaliação foi realizada no período de transição do esmalte, onde a matriz sofre uma pequena retração. Do ponto de transição, 
determinado visualmente, foram realizadas avaliações a cada $700 \mu \mathrm{m}$, até o desaparecimento da matriz. Em uma região onde não havia qualquer vestígio de matriz ou estrutura tecidual, foi determinado o ponto zero em relação à leitura de densidade.

\section{7 - TRATAMENTO ESTATÍSTICO}

A análise dos dados foi realizada por meio de testes paramétricos sobre variáveis quantitativas de amostras independentes. Os valores de cada grupo foram comparados entre si, dois a dois, pela análise de variância ANOVA, ou teste $\mathrm{F}$ de Snedecor, do programa estatístico ARCUS. O nível de probabilidade de erro foi fixado em 5\% (P $<0,05)$ para demonstrar possíveis diferenças estatisticamente significantes. Calculou-se ainda, o desvio padrão (S) das médias obtidas a fim de se determinar variações entre as amostras. 


\section{5 - RESUlTADOS}




\section{5 - Resultados}

Os resultados foram obtidos de acordo com análises morfológica descritiva microscópica e macroscópica. Os aspectos microscópicos foram ainda submetidos à análise quantitativa, medindo-se o comprimento da matriz remanescente e avaliando-se a densidade óptica das regiões correspondentes aos estádios de transição e maturação, por meio de programas específicos para a análise de imagens.

\section{1 - MASSA CORPORAL}

A massa corporal dos espécimes do grupo controle e experimentais, foi aferida, em gramas, por meio de uma balança de precisão, no Biotério Central da Faculdade de Odontologia de BauruUSP, durante seis semanas. A primeira pesagem foi feita nove dias após os animais terem sido desmamados, quando completaram 30 dias de vida pós-natal e sete dias de experimento. 
Tabela 2 - Médias semanais das massas corporais (em mg) dos espécimes dos grupos I, II, e III

\begin{tabular}{|c|c|c|c|}
\hline Período & $\begin{array}{c}\text { Grupo la } \\
\bar{X} \pm S^{*}\end{array}$ & $\begin{array}{c}\text { Grupo Ilb } \\
\overline{\mathbf{X}} \pm S\end{array}$ & $\begin{array}{c}\text { Grupo IIIc } \\
\overline{\mathbf{X}} \pm \mathrm{S}\end{array}$ \\
\hline 1 a semana & 71,4 & 65,2 & 76,0 \\
\hline$(30 \text { dias })^{* \star}$ & $\pm 6,8$ * & $\pm 5,3$ & $\pm 6,0$ \\
\hline 2 a semana & 110,0 & 109,4 & 121,8 \\
\hline (37 dias) & $\pm 12,0$ & $\pm 10,7$ & $\pm 10,2$ \\
\hline 3 a semana & 127,6 & 127,0 & 134,0 \\
\hline (44 dias) & $\pm 13,2$ & $\pm 10,7$ & $\pm 12,7$ \\
\hline 4 a semana & 136,5 & 137,4 & 138,4 \\
\hline (51 dias) & $\pm 13,5$ & $\pm 7,6$ & $\pm 10,6$ \\
\hline 5 a semana & 155,8 & 154,8 & 153,4 \\
\hline (58 dias) & $\pm 14,6$ & $\pm 8,1$ & $\pm 13,6$ \\
\hline 6 a semana & 171,4 & 165,8 & 169,6 \\
\hline (65 dias) & $\pm 16,3$ & $\pm 7,5$ & $\pm 11,1$ \\
\hline
\end{tabular}

a,b / a,c / b,c P $<0,05$

$*$ *Idade dos animais

A análise estatística dos dados semanais de massa corporal, entre os grupos experimentais, não mostrou diferenças estatisticamente significantes. 


\section{2 - CONSUMO SEMANAL DE ÁGUA}

O consumo de água foi mensurado, em mililitros, duas vezes a cada semana experimental, que envolveram os meses de maio e junho de 1999. O método consistia em preencher as jarras de cada caixa com cinco animais, com 500ml. Decorridas aproximadamente 48 horas, foram medidas as sobras de cada jarra. A partir dos valores obtidos com as sobras de cada jarra, resultou a média, por grupo, de consumo de água.

Tabela 3 - Média do consumo diário de água para cada animal dos grupos I, II e III

\begin{tabular}{c|c|c|c}
\hline Período & Grupo I & Grupo II & Grupo III \\
\hline 1 a semana & 20,57 & 21,71 & 22,28 \\
2 a semana & 22,28 & 21,14 & 22,85 \\
3 a semana & 25,14 & 25,71 & 28,57 \\
4 a semana & 15,42 & 18,57 & 22,85 \\
5 a semana & 16,00 & 18,00 & 18,57 \\
6 a semana & 18,28 & 18,00 & 28,57 \\
$\bar{X} \pm S^{*}$ & $19,61 \pm 1,54^{* a}$ & $20,52 \pm 1,22 b$ & $23,95 \pm 1,60 c$ \\
\hline
\end{tabular}


A tabela três mostra que o consumo médio de água, por animal, esteve em torno de $20 \mathrm{ml}$ por dia. A análise estatística demonstrou não haver diferenças significantes entre os três grupos estudados, ao longo das seis semanas.

\section{3 - MORFOLOGIA MACROSCÓPICA}

Os incisivos de ratos, ao irromperem, apresentam caracteristicamente uma camada superficial uniforme, com pigmentação acastanhada vinda da impregnação pelo elemento ferro. Nos animais experimentais que ingeriram água deionizada e com sete ppm de fluoreto de sódio, podia-se observar tais características (Figura $1)$.

O grupo I desse trabalho, submetido à dieta com água contendo $100 \mathrm{ppm}$, dose considerada tóxica, demonstrou alterações na pigmentação do esmalte, cuja superfície apresentava-se esbranquiçada, com discretas estriações transversais de cor amarelada, evidenciando as bandas incrementais de formação e mineralização do esmalte (Figura 1). A refração de luz sobre a superfície do esmalte apresentava-se diminuída, uma vez que se observou a perda de brilho e translucidez do mesmo. 


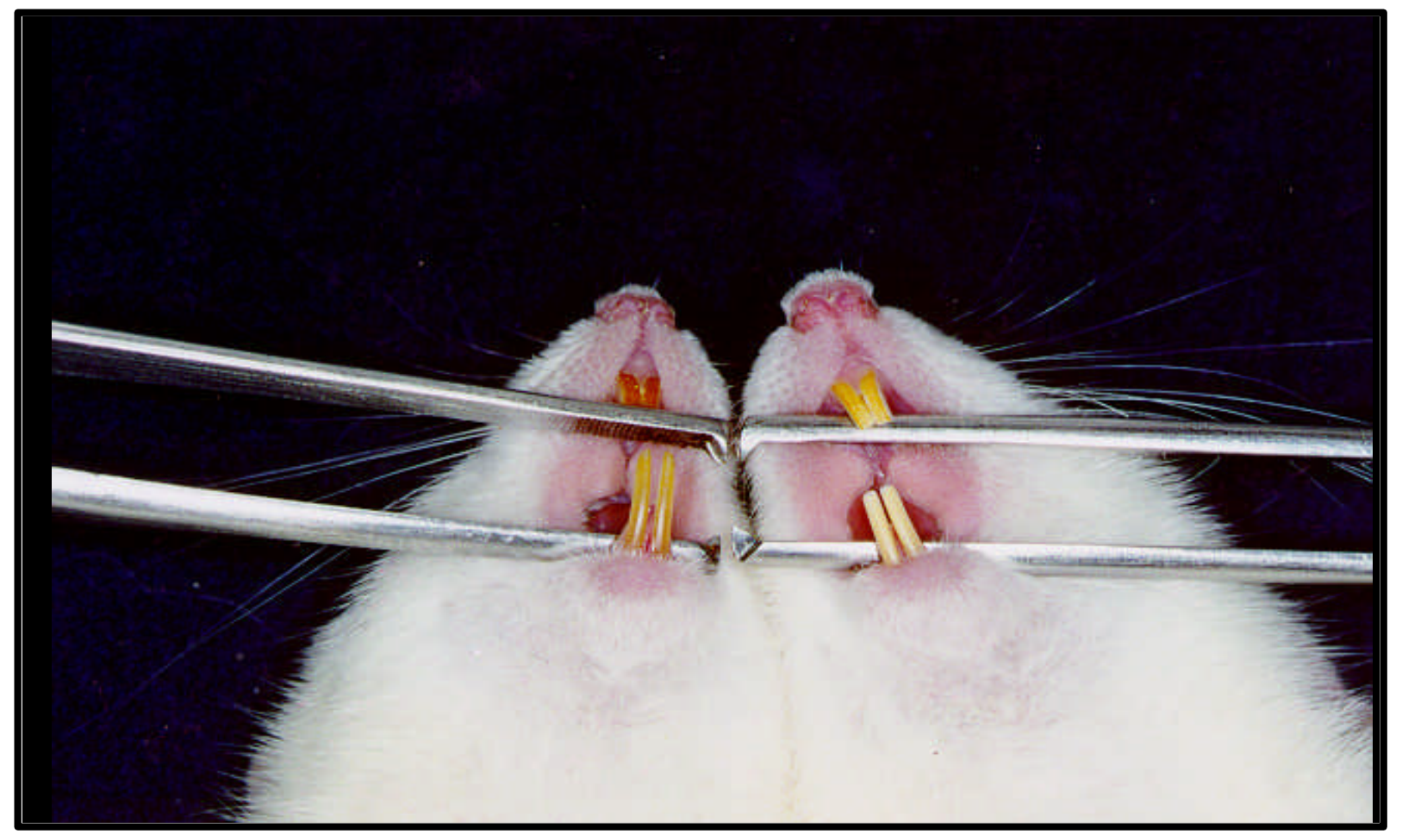

FIGURA 1 - Aspecto macroscópico dos incisivos dos animais do grupo de 100 (I) e sete (II) ppm. No rato do grupo I, à esquerda, nota-se um branqueamento do esmalte $\left(^{*}\right)$ causado pela hipomineralização decorrente da fluorose dentária. No animal do grupo II, observa-se pigmentação amarelada dos incisivos conforme os padrões de normalidade. 


\section{4 - MORFOLOGIA MICROSCÓPICA}

\subsubsection{Análise descritiva}

A microscopia óptica revelou quadros semelhantes em praticamente todos os cortes estudados. Os aspectos microscópicos mostravam fragmentos de hemimandíbula de rato compostos por três molares e um incisivo, seccionados aproximadamente em plano paralelo ao longo eixo dessas estruturas. Apresentavam-se circundadas, ora parcialmente, ora totalmente, por tecido conjuntivo densamente colagenizado e celularizado. Nos planos profundos observou-se tecido ósseo, células adiposas, fibras musculares esqueléticas, bem como ácinos e ductos de glândulas salivares menores.

O sinal imuno-histoquímico não foi detectado nos controles negativos (Figura 2) e mostrou-se intenso por toda a matriz do esmalte dos incisivos (Figura 3), incluindo a junção amelodentinária dos mesmos e dos molares; ocorrendo um sinal moderado na porção apical do citoplasma dos ameloblastos. 


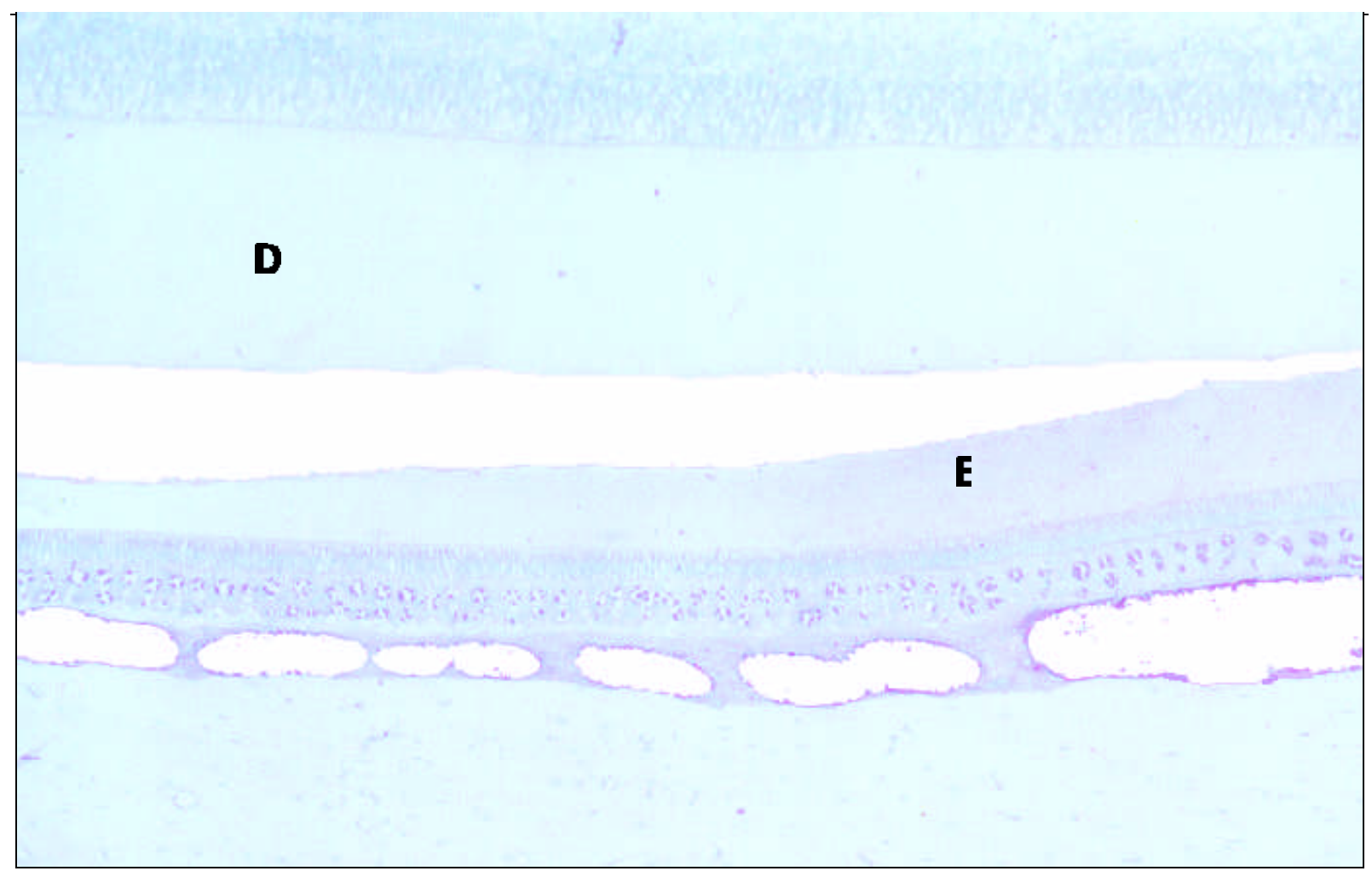

FIGURA 2 - Técnica imuno-histoquímica. Controle negativo mostrando a contra-coloração, sem a presença de marcações específicas para amelogeninas, no esmalte (E) e sem backgrounds na dentina (D) ou nas outras estruturas dentárias. Foi utilizado um corte microscópico do grupo II para exemplificar o controle negativo, sendo que os outros grupos apresentaram o mesmo padrão de controle negativo. A.O. $=32 \mathrm{X}$ 


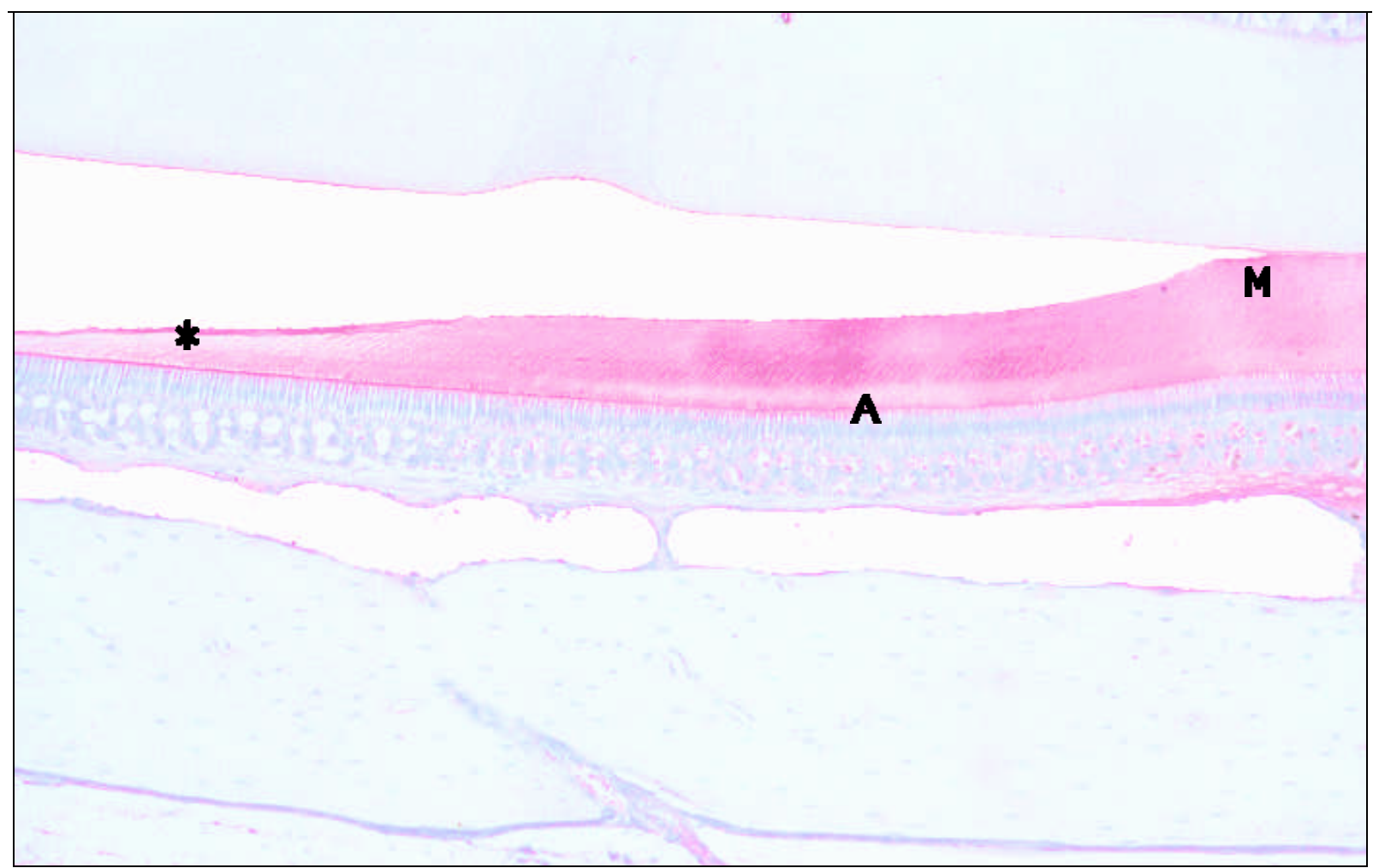

FIGURA 3 - Imuno-histoquímica do grupo experimental II. Figura exemplificando a presença do resultado positivo da técnica; revela coloração fúcsia, evidenciando a presença de amelogeninas na matriz (M) não mineralizada do esmalte dentário. Em algumas áreas como no esmalte aprismático (A) e na extremidade da matriz $(*)$, nota-se perda de intensidade de marcação.

$$
\text { A.O. }=32 X
$$


Detectou-se marcação inespecífica fraca em áreas como o complexo dentinopulpar, as fibras colágenas do tecido conjuntivo, em algumas células progenitoras hematopoiéticas da medula óssea e na superfície epitelial da mucosa bucal, quando presente no campo microscópico.

A matriz do esmalte apresentou variações discretas em sua homogeneidade. Na fase de secreção, o gel de matriz mostrou-se bastante homogêneo, sendo que essa característica se perdia com o avançar do processo de amelogênese. Na morfologia dos ameloblastos, houve alterações compatíveis com as fases de secreção, transição e maturação.

No início da fase de transição, alguns espaços negativos mais ou menos hexagonais entre as áreas marcadas pela imunohistoquímica começavam a tornar-se evidentes (Figura 4). As áreas negativas encontravam-se dispostas como se estivessem empilhadas, dirigindo-se desde a região de esmalte aprismático, onde a disposição descrita apresentava-se caracteristicamente desorganizada, até as proximidades da junção amelodentinária. 


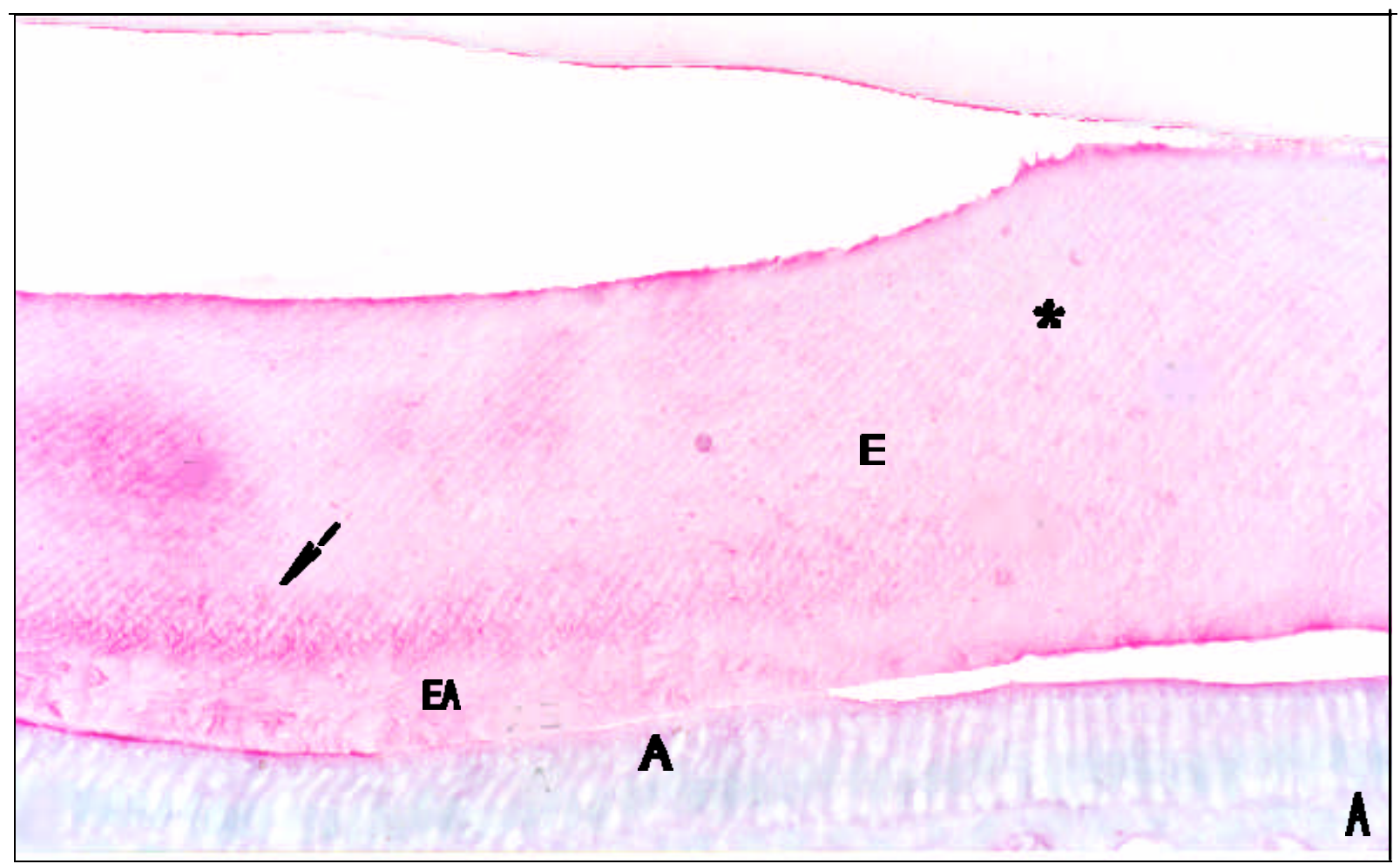

FIGURA 4A - O corte microscópico do grupo I, revela matriz de esmalte (E) marcada por imuno-histoquímica na fase identificada morfologicamente como de transição $\left(^{*}\right)$, onde a mesma sofre uma pequena retração vista em todos os cortes. Observam-se pequenas áreas negativas correspondentes aos prismas de esmalte (seta), que terminam desordenadamente no esmalte aprismático (EA), sobrejacente à camada de ameloblastos (A). A.O. $=128$ 


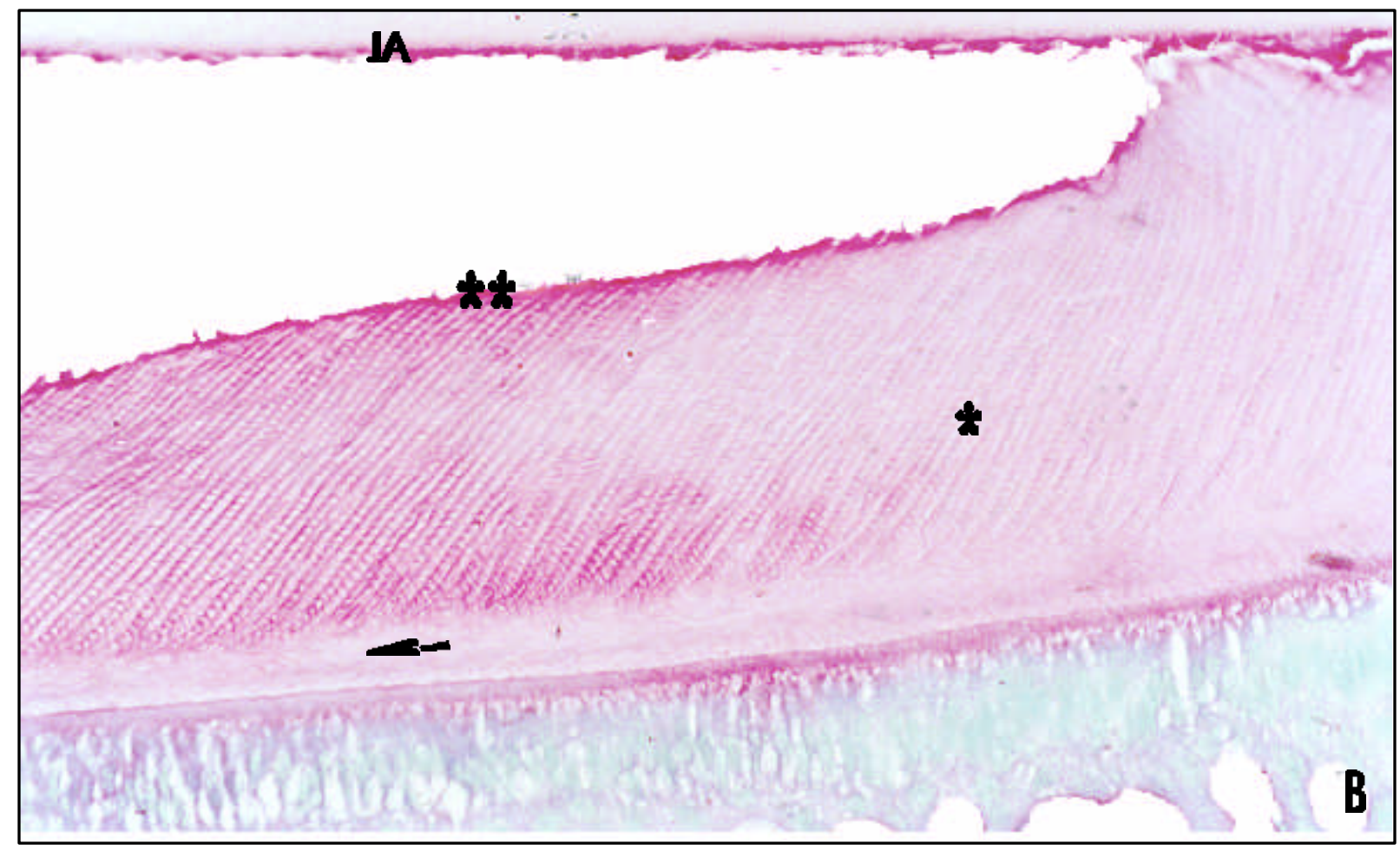

FIGURA 4 B - Aspecto microscópico do grupo Il na mesma área referida na figura 4A, mostra uma pequena alteração na intensidade de marcação, aproximadamente no centro da matriz (*) e no esmalte aprismático (seta). A coloração parece mais intensa na junção amelodentinária (JA) e na borda livre da matriz $(* *)$.

$$
\text { A.O. }=128 \mathrm{X}
$$




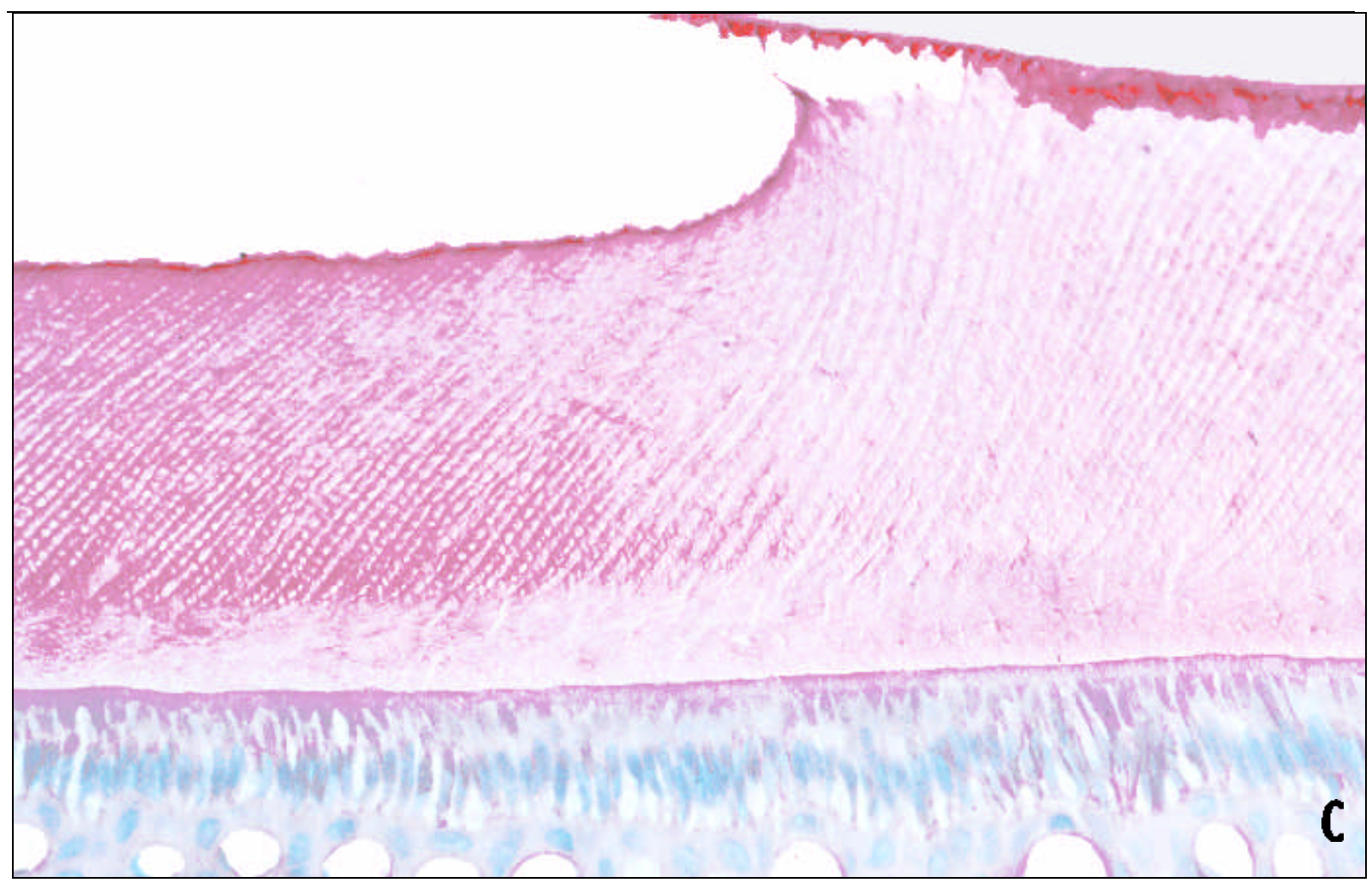

FIGURA 4 C - No grupo três, representado na figura, os padrões de marcação são semelhantes aos dos outros grupos, principalmente ao II.

A.O. $=128 \mathrm{X}$ 
No grupo I, a matriz na área de transição pareceu conter espaços negativos menores, podendo esse aspecto ser considerado um indicador morfológico do atraso na remoção das proteínas do esmalte. Os espaços hexagonais referidos nos três grupos correspondem aos primeiros cristais de apatita nucleados na matriz, que aumentam gradativamente até ocuparem, de modo coordenado, quase todo o espaço do material orgânico do esmalte em formação (Figura 5).

Nos incisivos tratados com água deionizada (GIII) e com água contento 7ppm (GII) de fluoreto de sódio, a matriz protéica estendia-se até a direção das raízes mesiais dos segundos molares. Tal observação tornou-se possível devido à anatomia mandibular dos ratos, onde o longo incisivo, com sua característica de irrompimento contínuo, passa por baixo das raízes dos molares. Em animais tratados com 100 ppm (GI), a retenção da matriz podia ser evidenciada no momento em que, ao comparar-se com os outros dois grupos, a maior extensão do remanescente de matriz desde o início da fase de maturação, ou fase de transição, até o seu final (Figura 6). 


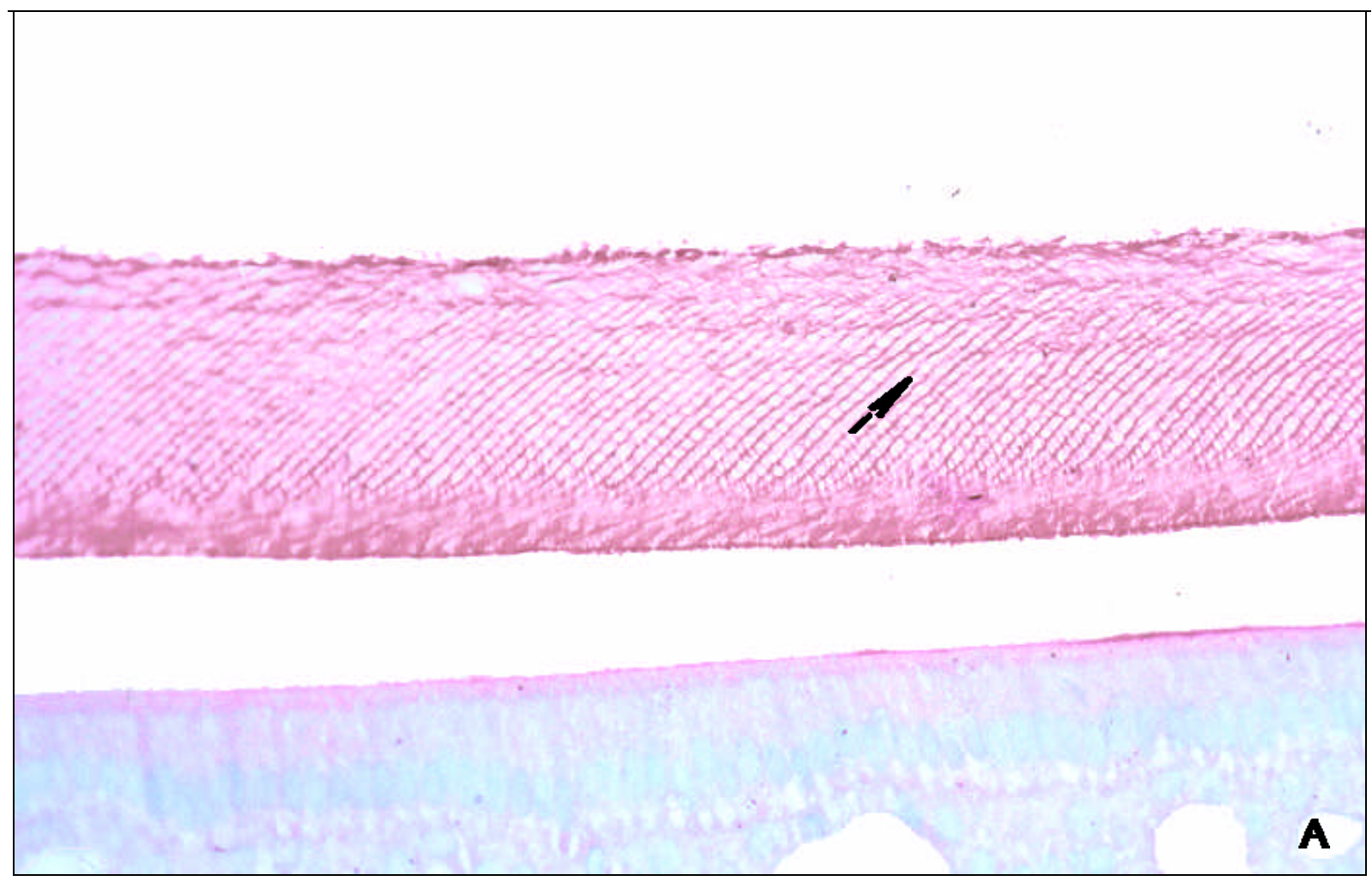

FIGURA 5 A - Matriz orgânica ao longo da fase de maturação, exibindo aumento dos espaços entre o esmalte interprismático (seta), correspondente aos prismas do mesmo, indicando morfologicamente a presença de atividade degradativa e reabsortiva sobre as proteínas de matriz. A.O. $=128 \mathrm{X}$ 


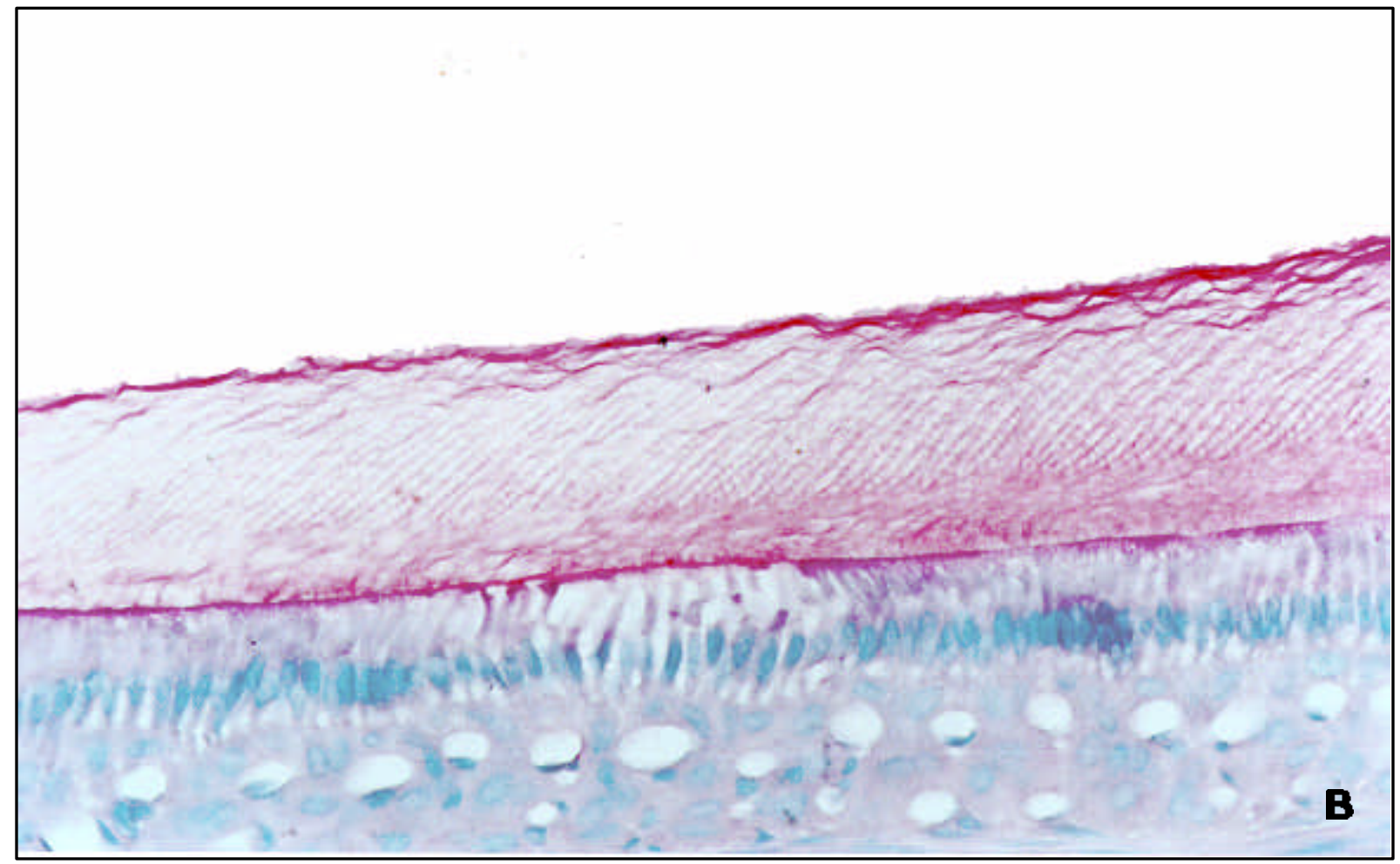

FIGURA 5 B - A matriz em maturação do grupo II, demonstra o mesmo padrão morfológico da figura $5 \mathrm{~A}$, onde se expandem os espaços negativos (*) entre o esmalte interprismático.
A.O. $=128 \mathrm{X}$ 


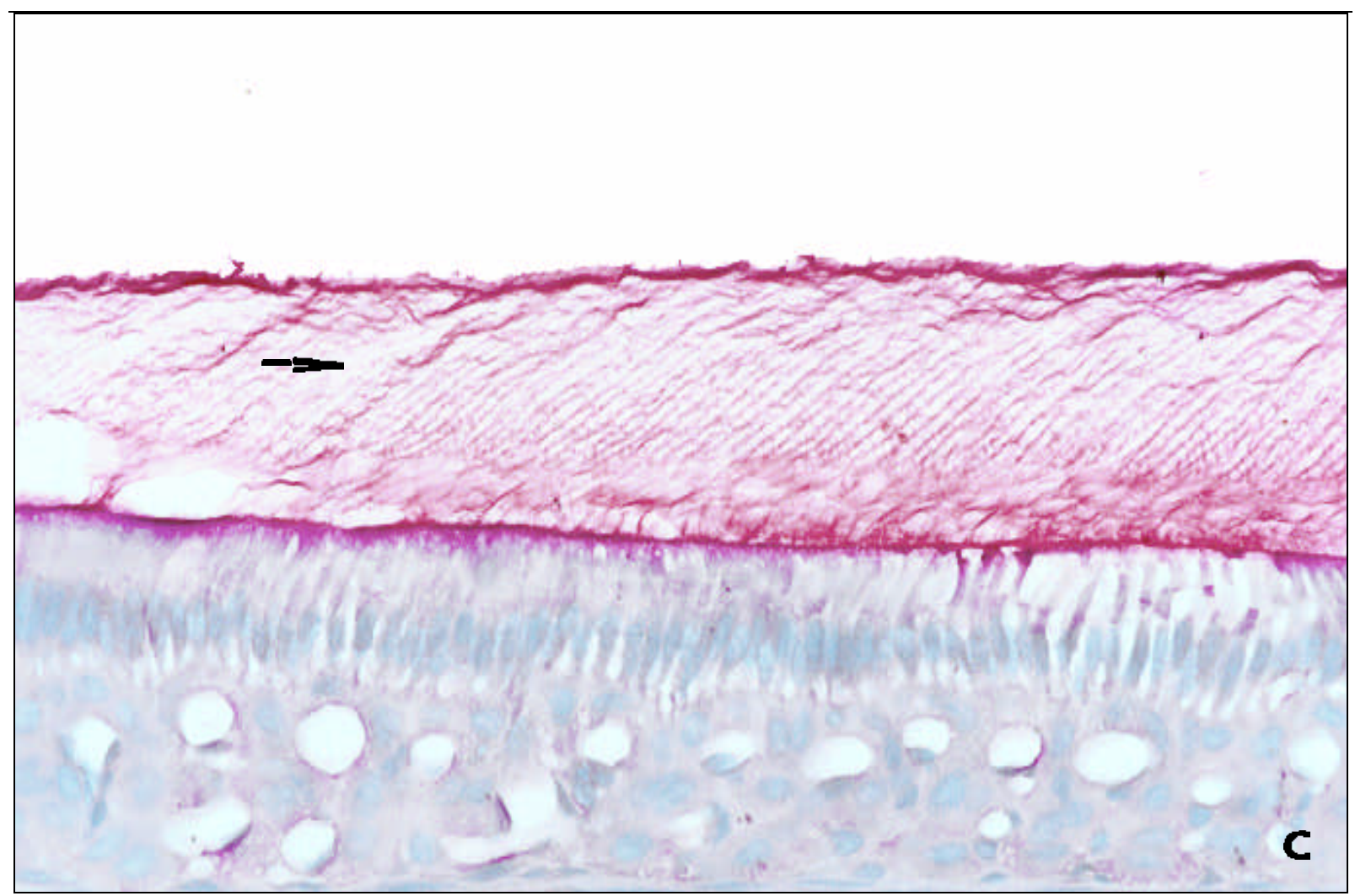

FIGURA 5 C - Grupo controle, onde se observa uma matriz de esmalte com aspecto rendilhado (seta), semelhante as dos grupos experimentais.

A.O. $=128 \mathrm{X}$ 


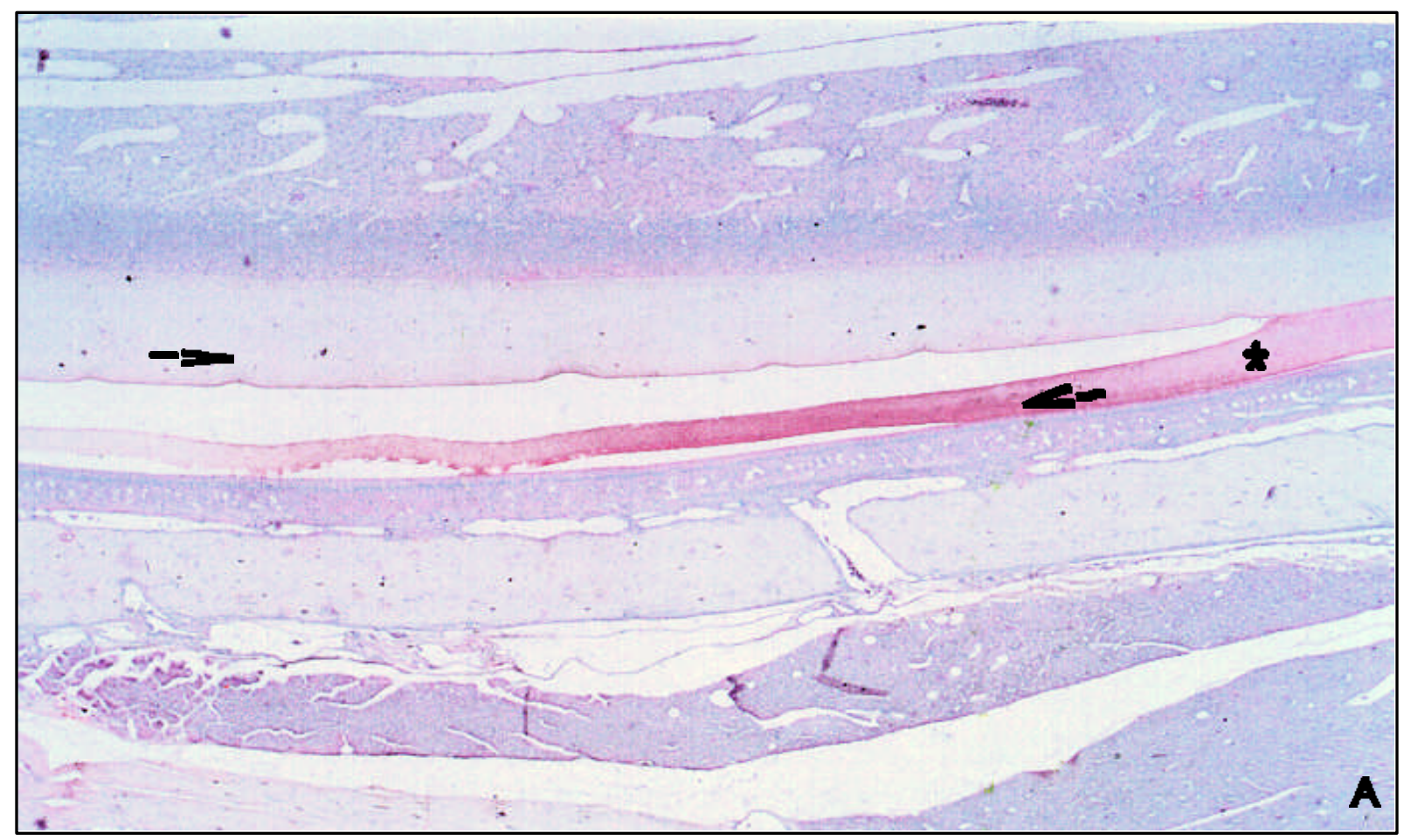

FIGURA 6 A - Matriz do esmalte fluorótico, grupo I. Nota-se a manutenção dos remanescentes protéicos, estendendo-se desde o início do período de maturação (*), em direção a extremidade incisal do dente (seta).

$$
\text { A.O. }=12,8 \mathrm{X}
$$




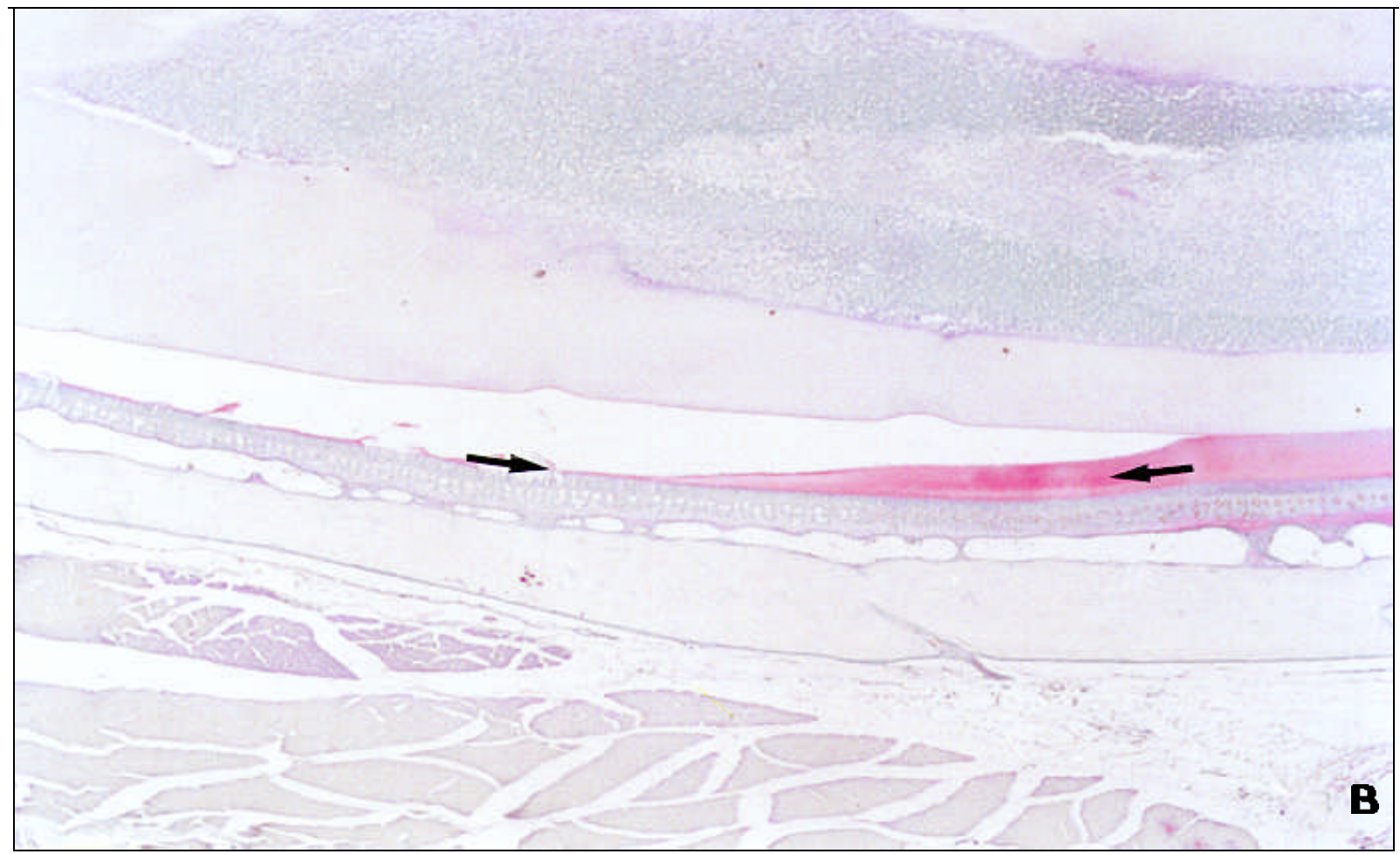

FIGURA 6 B - Aspecto morfológico do grupo tratado com sete ppm de fluoreto de sódio, onde o comprimento linear da matriz em maturação parece reduzido (setas) em relação ao mesmo nos espécimes tratados com 100 ppm.

A.O. $=12,8 \mathrm{X}$ 


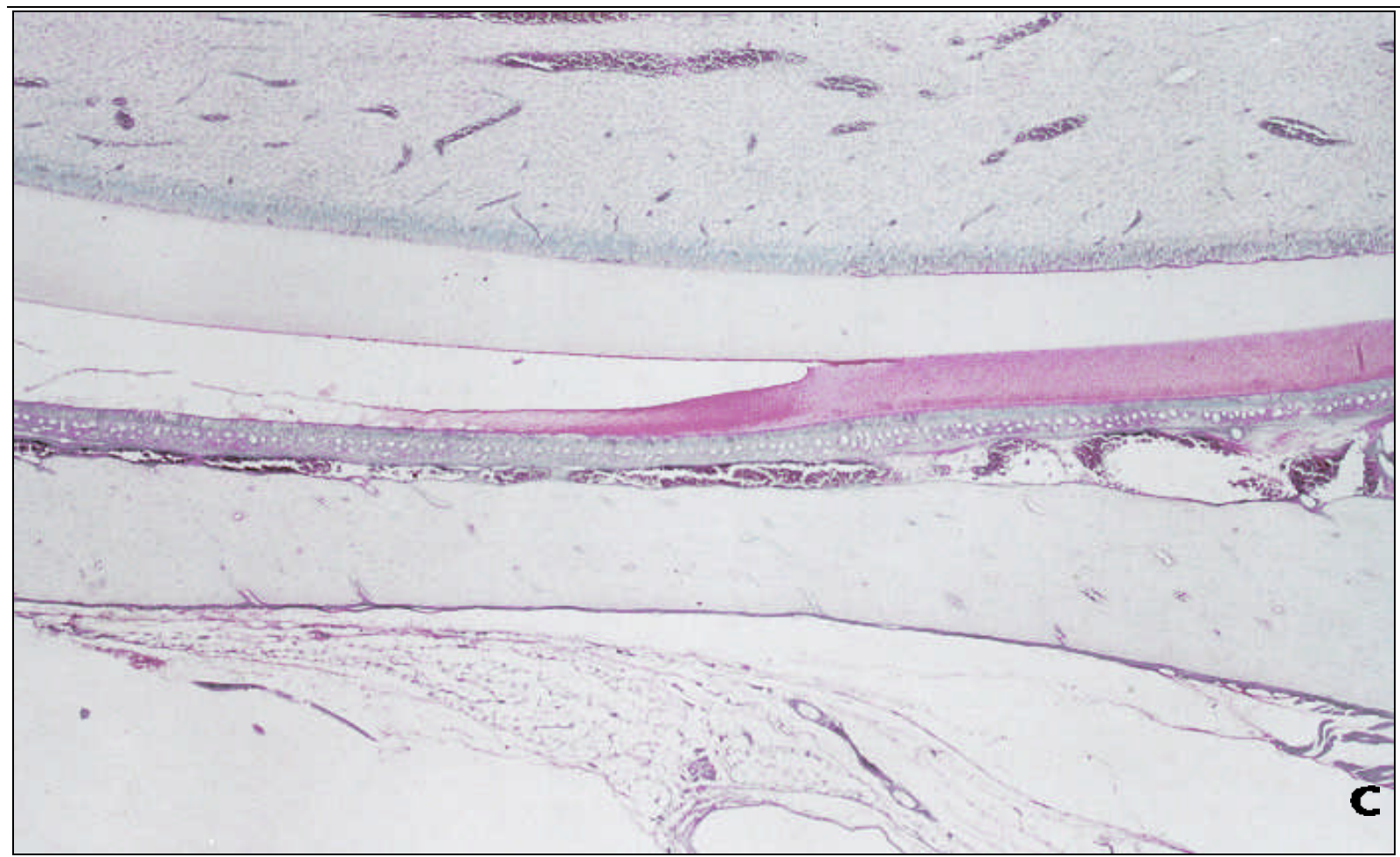

FIGURA 6 C - A microscopia do incisivo de rato do grupo controle assemelha-se a do grupo II, indicando morfologicamente a falta de toxicidade da água com sete ppm de fluoreto de sódio, para o modelo experimental adotado.

$$
\text { A.O. }=12,8 \mathrm{X}
$$




\subsection{2 - Análise quantitativa}

5.4.2.1. Comprimento linear da matriz do esmalte

Para a obtenção do comprimento linear total da matriz do esmalte, foram selecionados os cortes que mais se adequavam à técnica de medição pelo analisador de imagens do tipo Kontron KS300 (Kontron Eletronic GMBM), sendo esses os que exibiam a matriz íntegra desde o início de sua secreção na papila dentária ou porção basal do órgão do esmalte até o seu remanescente final, na área correspondente ao estádio de maturação.

A análise da matriz na fase de maturação foi feita a partir da eleição de dois pontos referenciais. O inicial, correspondente à área de transição da matriz e o segundo, localizado no final da matriz remanescente. Um terceiro grupo de dados obtidos foi relativo ao comprimento linear da fase de secreção da matriz dos cortes analisados. Para tanto, foram subtraídas as médias referentes à fase de maturação, das medidas do comprimento total da matriz. O resultado médio dos três valores obtidos foi de $4,6 \mathrm{~mm}$, sem apresentar diferenças estatisticamente significantes entre eles. 
Tabela 4 - Médias do comprimento linear total e da fase de maturação da matriz do esmalte de incisivos de ratos com consumo de água com 100 ppm de fluoreto de sódio (G I), com sete ppm (G II) e deionizada (G III). Valores obtidos em milímetros

\begin{tabular}{c|c|c}
\hline Grupos experimentais & Comprimento total & Fase de maturação \\
\hline I & $9,94 \pm 0,63^{*}$ & $5,32 \pm 0,46^{*}$ \\
II & $6,25 \pm 1,07$ & $2,06 \pm 0,21$ \\
\hline III & $6,79 \pm 1,12$ & $1,81 \pm 0,12$ \\
\hline $\mathrm{X} \pm \mathrm{S}^{*}$ & & \\
\hline
\end{tabular}

Análise de variância e nível de significância entre as medidas totais das matrizes dos três grupos:

I e II: $F=71,33 ; p<0,01$

I e III: $F=48,75 ; p<0,01$

II e III: $F=0,93 ; p>0,05$ 
Análise de variância e nível de significância do comprimento da matriz em maturação, dos grupos envolvidos no experimento:

Grupos I e II: $F=40,01 ; p<0,01$

Grupos I e III: $F=52,01 ; p<0,01$

Grupos II e III: $F=1,04 ; p>0,05$

5.4.2.2. Densidade da matriz do esmalte

A densidade da matriz do esmalte foi obtida da área correspondente ao início da fase de transição até um ponto final onde ainda havia a possibilidade de mensuração, situado na matriz de maturação preservada durante o processo de desmineralização pelo EDTA (Figura 7). A área referida foi medida linearmente antes da análise de imagens. 


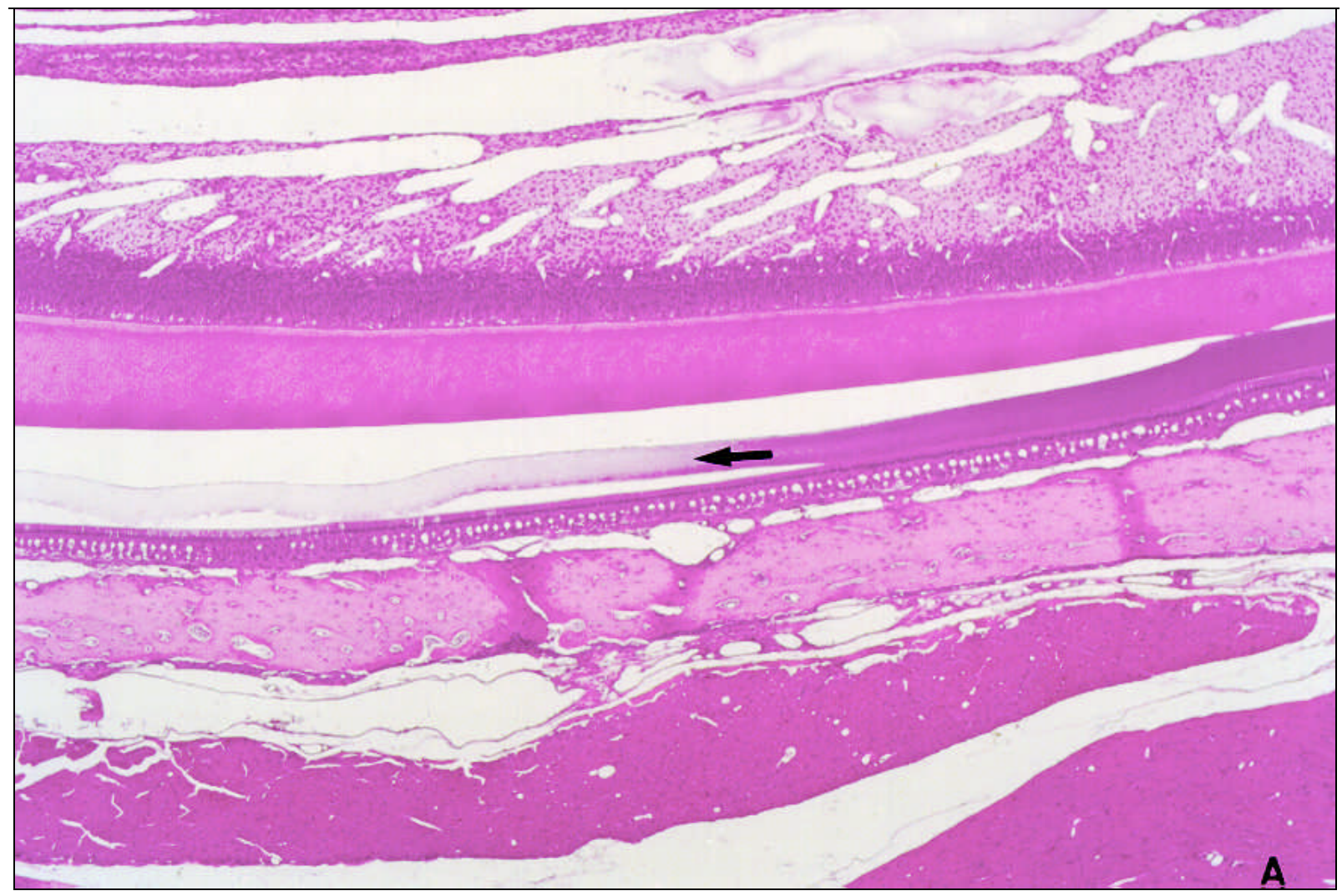

FIGURA 7 A - O quadro microscópico em menor aumento demonstra, em H.E., a perda de intensidade de coloração concomitante ao avançar do processo de mineralização da matriz do esmalte (seta). Espécime do grupo I, utilizado para ilustrar o aspecto morfológico acima. A.O. $=12,8 \mathrm{X}$ 


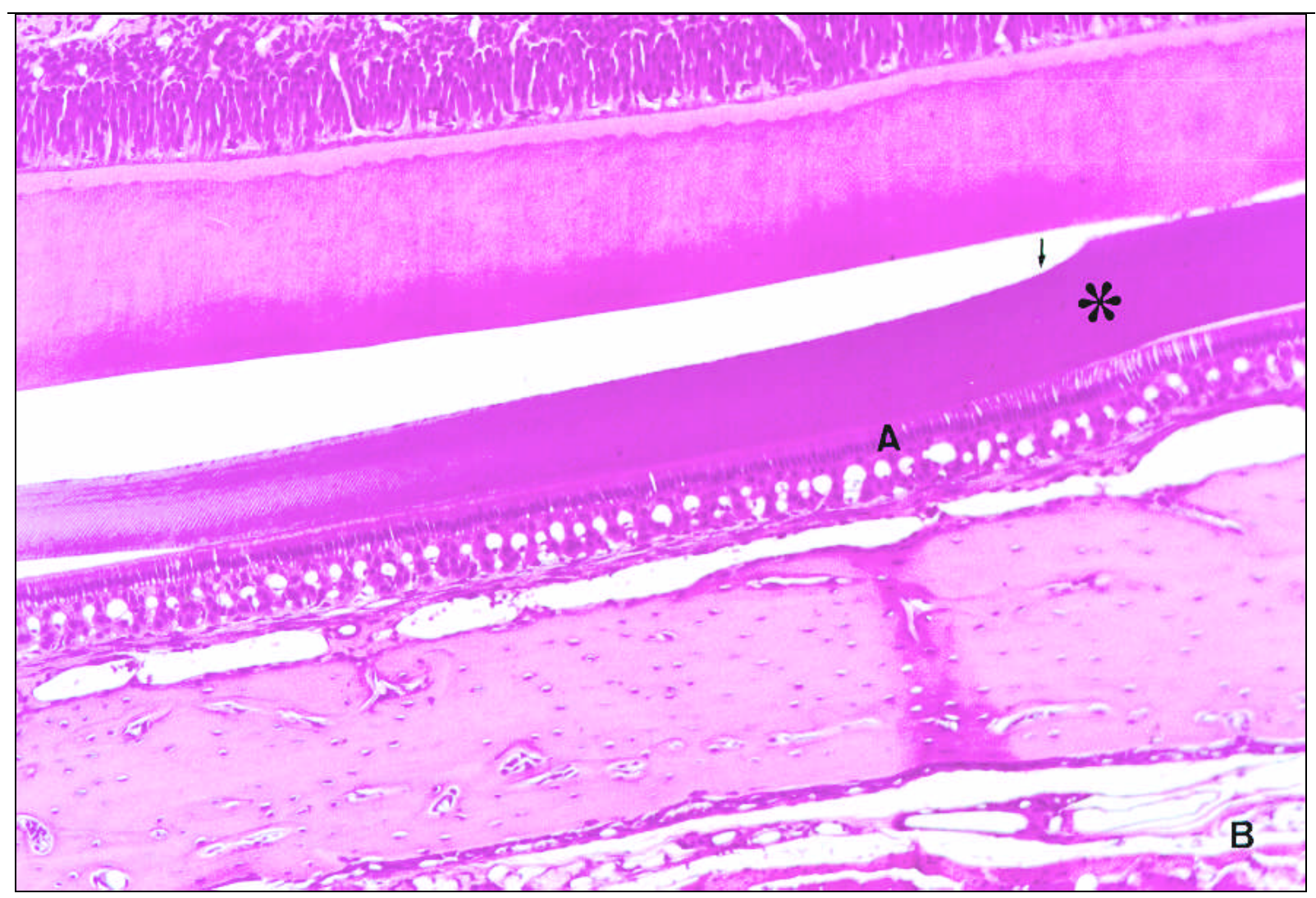

FIGURA 7 B - Detalhe da área considerada como início da fase de maturação, ou zona de transição (*), onde a matriz sofre retração transversal (seta) e os ameloblastos (A) apresentam discreto encurtamento em seu longo eixo. Corte em H.E. do grupo I, utilizado na mensuração da densidade da matriz.

A.O. $=32 X$ 
Tabela 5 - Média e desvio padrão da densidade óptica da matriz do esmalte, em um ponto inicial $(0 \mu \mathrm{m})$ correspondente a fase de transição e em segmentos de $700 \mu \mathrm{m}$, previamente determinados ao longo da fase de maturação. Na escala de densidade são determinados escores, denominados unidades gray, que variam entre 0 e 255 unidades

\begin{tabular}{|c|c|c|c|}
\hline PONTOS & $\begin{array}{c}\text { Grupo I } \\
\qquad \mathrm{X}_{ \pm} \mathrm{S}^{*}\end{array}$ & $\begin{array}{c}\text { Grupo II } \\
\qquad \mathrm{X} \pm \mathrm{S}\end{array}$ & $\begin{array}{c}\text { Grupo III } \\
\qquad X \pm S\end{array}$ \\
\hline $0 \mu \mathrm{m}$ & $138,25 \pm 2,78^{*}$ & $140,62 \pm 8,09 *$ & $132,97 \pm 3,73^{*}$ \\
\hline $700 \mu \mathrm{m}$ & $118,50 \pm 1,29$ & $58,56 \pm 13,80$ & $57,34 \pm 13,49$ \\
\hline $1400 \mu \mathrm{m}$ & $76,36 \pm 1,41$ & $18,25 \pm 3,62$ & $22,09 \pm 5,77$ \\
\hline $2100 \mu \mathrm{m}$ & $27,20 \pm 0,64$ & - & - \\
\hline $2800 \mu \mathrm{m}$ & $17,46 \pm 4,25$ & - & - \\
\hline $3500 \mu \mathrm{m}$ & $8,64 \pm 2,06$ & - & - \\
\hline $4200 \mu \mathrm{m}$ & $3,40 \pm 0,28$ & - & - \\
\hline
\end{tabular}


Análise de variância e nível de significância obtida a partir dos valores de densidade nos pontos mensuráveis de todos os grupos:

Grupos I e II: $F=7,65 ; p>0,05$. No ponto $0 \mu \mathrm{m}$

$$
\begin{aligned}
& F=18,70 ; p<0,01 . \text { No ponto } 700 \mu \mathrm{m} \\
& F=227,55 ; p<0,01 . \text { No ponto } 1400 \mu \mathrm{m}
\end{aligned}
$$

Grupos I e III: $F=1,29 ; p>0,05$. No ponto $0 \mu \mathrm{m}$

$$
\begin{aligned}
& F=20,36 ; p<0,01 . \text { No ponto } 700 \mu \mathrm{m} \\
& F=83,59 ; p<0,01 . \text { No ponto } 1400 \mu \mathrm{m}
\end{aligned}
$$

Grupos II e III: $F=0,74 ; p>0,05$. No ponto $0 \mu \mathrm{m}$

$$
\begin{aligned}
& F=0,00 ; p>0,05 . \text { No ponto } 700 \mu \mathrm{m} \\
& F=0,31 ; p>0,05 . \text { No ponto } 1400 \mu \mathrm{m}
\end{aligned}
$$


6 - DISCUSSÃO 


\section{6 - Discussão}

A fluorose dentária constitui-se em um distúrbio do desenvolvimento com etiologia bem definida e patogenia controversa. Ao procurar entender porque o excesso de flúor modifica o esmalte com graus variáveis de severidade, foram estabelecidas linhas de pesquisa ao longo dos anos a fim de buscar no mecanismo de biomineralização e em todas as suas particularidades, as respostas para o processo de desenvolvimento da fluorose $19,52,77,82,86$.

Reportando-se à biomineralização, definida como um somatório de eventos que não ocorre simplesmente pela combinação de íons cálcio e fosfato, mas resulta da interação de fatores biológicos e físico-químicos, os estudiosos da fluorose se depararam com a produção e secreção da matriz não colagênica do esmalte, que proporciona um substrato ideal para a biomineralização, bem como interage com o componente mineral a ser formado45,92, denominado em alguns tópicos como matriz inorgânica. 
Na fluorose dentária, a amelogênese sofre a interferência de compostos fluoretados ou mesmo de íons flúor lábeis ${ }^{34}$ que, a princípio hipoteticamente, poderiam interferir na diferenciação ou função das células produtoras de matriz ${ }^{13,37}$, poderiam alterar a interação das proteínas com a superfície dos cristalitos formados 86,87 ou ainda, poderiam inibir a função das enzimas proteolíticas designadas a degradar a matriz no momento propício33,34.

A fundamentação dessas três hipóteses relativas à patogenia da fluorose dentária tem uma característica comum, concorda-se que a porção protéica da matriz fica retida após o início da fase de maturação do esmalte, momento em que deveriam ser removidas paulatinamente até serem quase totalmente endocitadas pelos mesmos ameloblastos que as produziram e secretaram $21,47,51$.

A confirmação experimental da permanência da matriz do esmalte, frente à fluorose, se deu com base em estudos que definiam quais eram as proteínas inerentes ao tecido em questão e quais eram suas funções 25,31,38. Observou-se que as amelogeninas perfaziam aproximadamente $95 \%$ do montante protéico da matriz. Entre suas atribuições, estão sua capacidade de modular o crescimento cristalino 
do esmalte e de servir de suporte para a formação organizada dos cristais de apatita29,30,62.

A correlação entre as propriedades das amelogeninas e o mecanismo pelo qual se dá a fluorose dentária tornou-se uma peça chave para o entendimento da sua patogenia. Para tanto, houve a necessidade de padronização e reprodutibilidade experimental da fluorose, o que levou à proposição de diferentes modelos experimentais, dentre os quais os roedores 58 .

Os ratos da linhagem Wistar, que representaram o modelo experimental adotado nesse trabalho, possuem dentição monofiodonte e cada quadrante de seus maxilares apresenta três molares e um incisivo, sendo esse último caracterizado por seu crescimento, mineralização e irrompimento contínuos. Em um rato adulto, existe a possibilidade de se observar marcas metabólicas registradas na estrutura incremental do esmalte. O tempo de registro varia entre $40-$ 45 dias precedentes. A curvatura dos incisivos inferiores pode ser considerada como um pequeno segmento de uma espiral de 1400 a 1500, que não se completa devido à atrição constante ocorrida entre os incisivos inferiores e superiores. A histogênese dos incisivos de ratos 
permite o estudo de todos os momentos da formação dos dentes em um só, o que se torna interessante por haver desse modo menos variáveis a serem superadas 67.

Os grupos de animais utilizados pertenciam ao Biotério Central da Faculdade de Odontologia de Bauru, USP. Sua dieta e condições de cativeiro foram controladas, o que permitiu a redução de variáveis individuais, em comparação ao grande número delas observado em condições naturais. Razão pela qual optou-se por uma amostra contendo 15 ratos distribuídos em três grupos, um número condizente com estudos que adotaram metodologia semelhante 20,28,95.

Como parte da coleta dos dados, mensurou-se a massa corporal e consumo de água, por haver possíveis diferenças em animais com fluorose induzida em relação aos dos grupos em que não se pretendia observar o distúrbio. Na seleção da concentração de fluoreto de sódio e do modo de administração do composto, optou-se pela forma crônica de ingestão na água de consumo diário. Uma forma viável por poder ser controlada e por já apresentar resultados satisfatórios na literatura20,28,95. 
As dosagens experimentais escolhidas de $7 \mathrm{ppm}$ e $100 \mathrm{ppm}$, representam, respectivamente, concentrações similares às encontradas na água de abastecimento urbano $(0,7 \mathrm{ppm})$ de nossa região e a dose considerada tóxica $(10 \mathrm{ppm})^{58,77}$.

A matriz de esmalte que, frente à fluorose, se mineraliza sem a apropriada nucleação e alongamento dos cristais gera uma estrutura porosa e friável, com excesso de componentes protéicos. As proteínas retidas nesse tipo de matriz podem ser identificadas com especificidade variável de acordo com o método de estudo eleito ${ }^{23}$. Por meio de imuno-histoquímica as amelogeninas podem ser marcadas com anticorpos primários antiamelogeninas e analisadas em microscopia óptica de luz ou eletrônica 23,51,71,73.

Para a execução da técnica imuno-histoquímica foi utilizado Kit LSAB2 (DAKO), que fornece o anticorpo secundário biotinilado obtido em coelhos, tal qual o primário, e o conjugado streptavidina/fosfatase alcalina que reage favoravelmente com 0 substrato cromogênico New Fucsin. O LSAB2 apresenta a característica de ser para uso exclusivo em espécimes de ratos e o resultado obtido evidencia em tons fúcsia as estruturas desejadas, sendo essa uma 
reação semipermanente. Optou-se pela fosfatase alcalina associada ao New Fucsin como substrato cromogênico para demonstrar com maior clareza a delgada estrutura estudada. A contracoloração, com verde de metila, permitiu um contraste satisfatório, como foi constatado no decorrer do experimento.

O anticorpo primário policlonal poderia deixar uma margem maior de possibilidade de backgrounds, como foi constatado durante a fase de teste piloto. Observou-se que haveria menos áreas marcadas inespecificamente se fosse usado na reação um inibidor de fosfatase alcalina endógena. Nesse trabalho, para a obtenção de tal resultado foi usado o ácido acético a $20 \% 56$, capaz de prover uma inibição de fosfatase alcalina endógena.

A comprovação quantitativa da preservação das amelogeninas na matriz foi feita por meio de medidas obtidas da análise dos cortes microscópicos no software Kontron KS300 (Kontron Eletronic GMBM), também capaz de analisar a densidade óptica da matriz do esmalte. Essa última análise foi realizada em cortes corados por H.E., permitindo que se constatasse de modo objetivo a permanência de uma 
quantidade maior de proteínas após a fase de transição da amelogênese.

Depois de estabelecida a metodologia e realizado o experimento, os resultados foram analisados e comparados com os de metodologias semelhantes22,77,95. Porém, antes do experimento propriamente dito foi realizado um grupo piloto com 12 animais para verificar a eficácia do método de perfusão intracardíaca, utilizado durante a eutanásia dos animais. Nesse mesmo grupo foram testados os anticorpos primários em diluições de 1:1500 e 1:3000. O resultado da imuno-histoquímica no teste piloto foi positivo, sendo que a diluição de 1:3000 foi preferida em razão da menor quantidade de marcações inespecíficas detectadas.

$\mathrm{Na}$ análise dos resultados, a morfologia macroscópica do grupo I diferenciou-se dos grupos II e III por apresentar dentes esbranquiçados, característicos de quadros de hipomineralização ou ainda, de desmineralização por fatores externos, como a clareação dentária. DENBESTEN; CRENSHAW20, em 1984, notaram alterações na pigmentação superficial de incisivos de ratos submetidos à dieta de $75 \mathrm{ppm}$, compatíveis com os aspectos encontrados nesse trabalho, onde 
as linhas amareladas observadas nos incisivos superiores atenuavamse nos inferiores, razão pela qual a descoloração do esmalte parecia mais difusa nos mesmos.

O comprimento da coroa clínica dos incisivos não foi mensurado, mas puderam notar-se diferenças em relação aos grupos comparados. No grupo de $100 \mathrm{ppm}$, os incisivos inferiores pareciam mais curtos que nos outros grupos. Observou-se ainda, que os antagonistas superiores mostravam-se mais longos em relação aos dos outros grupos. Quanto aos aspectos observados, que parecem denotar alterações no irrompimento dentário dos animais com fluorose, não foram buscadas correlações em outros experimentos, no entanto a confirmação de tais ocorrências poderá ser testada em futuros trabalhos relacionados aos efeitos clínicos da fluorose dentária.

A identificação imuno-histoquímica das amelogeninas apresentou um padrão difuso de marcação esperado, por duas razões principais. As amelogeninas ocupam praticamente todo o montante protéico do esmalte e os anticorpos sendo policlonais dariam uma pequena margem de inespecificidade quanto aos outros grupos de proteínas de matriz. Mesmo havendo tal limitação o uso de anticorpos 
policlonais se justificou devido à necessidade de reconhecimento de todas as isoformas de amelogeninas presentes no esmalte em formação.

Nos cortes microscópicos usados como controle negativo, onde se omitiu o anticorpo primário, os aspectos observados demonstravam germes dentários constituídos por tecido conjuntivo pulpar e matriz dentinária justaposta à matriz do esmalte. A camada de ameloblastos, representada por células predominantemente colunares dispostas em paliçada, encontrava-se subjacente à matriz por ela produzida, em íntimo contato com a camada papilar do órgão do esmalte do incisivo e com o osso mandibular do rato.

Os padrões de marcação imuno-histoquímica e morfológicos apresentaram imagens repetidas nas várias lâminas analisadas em cada grupo. Algumas variações foram observadas no grupo de 100 ppm, como disjunções entre os ameloblastos e a camada papilar, condizentes com as formações císticas relatadas por LANGE43 et al, que injetaram $30 \mathrm{mg} \mathrm{NaF} / \mathrm{kg}$ em ratos com 3, 4, 5 e 7 dias de vida. Observaram formações císticas subameloblásticas, correspondentes aos momentos onde foram aplicadas as doses de fluoreto de sódio, 
principalmente ao final da secreção. OLIVEIRA52, em 1988, ao estudar a morfologia dos ameloblastos secretores de incisivos de ratos com fluorose crônica induzida por injeções diárias de fluoreto de sódio, notou alterações apicais nos ameloblastos com aspecto cístico entre as referidas células e a matriz do esmalte, relacionando-as com os picos transitórios de flúor plasmático ocorridos após cada injeção.

A administração crônica de fluoreto não possibilita o controle preciso dos picos de flúor, no entanto a comparação do mesmo evento ocorrido nas duas situações, fluorose aguda e crônica, permitiu supor que, na fluorose induzida de forma crônica as formações císticas poderiam sinalizar, aproximadamente, os picos de flúor acrescido ao órgão do esmalte. Os autores dos trabalhos citados 43,52 relacionam ainda, as lesões encontradas com o nível de flúor plasmático.

$\mathrm{Na}$ interação do flúor com a matriz do esmalte poderia haver uma alteração estrutural nas amelogeninas, modificando seus epítopos, necessários para o reconhecimento antigênico. Caso o fluoreto de sódio interferisse bioquimicamente nas proteínas do esmalte estudadas, estaríamos frente a uma reação com pouca ou nenhuma intensidade de marcação. Esse aspecto não foi detectado, uma vez que os grupos 
experimentais e o controle mostraram-se com o mesmo padrão de marcação. As diferenças observadas foram quanto à quantidade e, por conseqüência, à extensão da matriz orgânica retida nos incisivos inferiores dos ratos.

As variações no desenvolvimento físico de animais experimentais podem ser usadas como parâmetros de comparação entre espécimes submetidos ou não a dietas contendo fluoretos na água de consumo diário. Registraram-se em alguns trabalhos, diminuições no ganho padrão de massa corporal em ratos 22,77,95 com fluorose crônica. Dessa forma, o aumento de massa pode ser considerado inversamente proporcional a concentração de flúor, um efeito dependente da dose administrada11,42,83.

No experimento de ZHOU et al95., houve diferenças mínimas na razão de aumento de massa corporal entre os grupos de ratos com fluorose avaliados por seis semanas. Com tais observações os autores sugeriram que, as alterações na secreção e remoção das proteínas do esmalte não seriam reflexo de modificações metabólicas sistêmicas, mas respostas locais às mudanças ocorridas no órgão do esmalte e na matriz. Os resultados deste trabalho, referentes ao desenvolvimento 
corporal dos animais experimentais não mostraram diferenças estatisticamente significantes entre os ratos que consumiram água deionizada, com sete e 100ppm de fluoreto de sódio.

Não houve diferenças estatísticas consideradas significativas quanto ao consumo de água durante o período experimental, sendo esse um outro parâmetro de comparação no estudo da fluorose. Em média cada rato bebeu $20 \mathrm{ml} /$ dia de água durante todo o período estudado. O máximo médio de consumo diário por animal aferido em uma semana foi de $28 \mathrm{ml}$ no grupo controle. Esses dados mostram que também não houve rejeição dos ratos do grupo experimental em relação ao consumo de água com 100ppm de fluoreto de sódio. No trabalho de SMITH; NANCl; DENBESTEN77, em 1993, os ratos consumiram em média $24 \mathrm{ml} /$ dia, num máximo de $35 \mathrm{ml} /$ dia de água com 100ppm de fluoreto de sódio. Os dados referentes à massa corporal e ao consumo de água são passíveis de alterações devido às variáveis sazonais e às diferentes concentrações de fluoretos, adotadas em cada experimento.

As doses empregadas de forma crônica na presente metodologia propiciaram a formação de um esmalte dentário conceitualmente hipomineralizado, presumindo-se que não houve 
danos funcionais nos ameloblastos capazes de desregular a produção e a secreção da matriz protéica. Atualmente, um dos focos de interesse no estudo da patogenia da fluorose direciona-se a partir da fase de transição da amelogênese, onde se iniciam uma remoção maciça das proteínas do esmalte e a formação de cristais constituídos por unidades de fosfato de octacálcio e um tipo de apatita carbonatada similar a hidroxiapatita encontrada usualmente na natureza 17,21,28.

Um dos objetivos deste trabalho foi determinar diferenças na remoção das amelogeninas de incisivos de ratos com e sem fluorose dentária, quantificadas pelo programa do analisador de imagens Kontron KS300 (Kontron Eletronic GMBM), da Carl Zeiss. O tratamento estatístico empregado aos valores da amostra permitiu a constatação de diferenças significantes entre as matrizes do grupo de $100 \mathrm{ppm}$ em relação às dos outros dois grupos. A compatibilidade dos valores de $7 \mathrm{ppm}$ de fluoreto de sódio e de água deionizada, pode ser considerada como um indicador da falta de toxicidade do flúor, na concentração adotada no grupo II.

O comprimento linear de toda a matriz do esmalte foi analisado para verificar se houve, ao longo da fase de secreção 
alguma alteração quantitativa nos incisivos com fluorose 76 . Subtraindo-se o comprimento do início da fase de maturação do total da matriz, verificou-se que, nos três grupos estudados, a produzida na fase secretora foi, em média, $4.6 \mathrm{~mm}$. Esses dados mostram que, sob a metodologia aplicada, o flúor não exerce influência na quantidade linear de matriz produzida e secretada.

Acredita-se que na fase de transição, quando começa a reabsorção em maior escala das amelogeninas, ocorre a liberação dos determinantes antigênicos das proteínas que ainda não foram reabsorvidas, aumentando a intensidade de marcação imunohistoquímica nesse momento. Esse foi um aspecto observado tanto nos grupos experimentais, quanto no controle. SHORE et al69., 1993, observaram o mesmo tipo de marcação mais intensa na fase de transição. Segundo os autores, durante toda a fase de secreção o complexo protéico que se forma mascara muitos epítopos, dificultando conseqüentemente a aplicabilidade da técnica. Embora a imunohistoquímica, tenha nos revelado esse detalhe morfológico, a alteração em sua uniformidade de marcação impediu-nos de avaliar a densidade da matriz pelo programa do analisador de imagens. Razão pela qual realizamos esse procedimento utilizando a coloração H.E., que 
demonstrou um grau de afinidade tintorial equilibrado durante a fase de secreção e a partir da transição, onde essa característica decresceu uniformemente em sentido incisal.

As observações morfológicas e os resultados de densidade mostraram que durante a fase de secreção a quantidade de matriz orgânica de esmalte secretada foi similar nos grupos estudados. O flúor nas concentrações de 7 e de 100ppm na água de consumo, parece não influenciar o metabolismo dos ameloblastos secretores e a organização da matriz secretada. Na escala de 0 a 255 unidades gray do método de densitometria, o máximo conseguido foi 140,62 para o grupo de $7 \mathrm{ppm}$ no ponto inicial da fase de transição, não havendo diferença estatística nos demais grupos nesse mesmo ponto. No grupo de $100 \mathrm{ppm}$, o ponto correspondente a $700 \mu \mathrm{m}$ apresentou um decréscimo de $14 \%$ em relação ao ponto inicial. Nos grupos de $7 \mathrm{ppm}$ e controle, nesses mesmos pontos o decréscimo foi de $58 \%$ e $57 \%$, respectivamente. No grupo de $100 \mathrm{ppm}$, o resultado observado no ponto de $700 \mu \mathrm{m}$ indicou que a densidade obtida foi cerca de duas vezes maior que as densidades dos outros grupos. 
No terceiro ponto de análise de densidade da matriz, de $1400 \mu \mathrm{m}$, o resultado do grupo de $100 \mathrm{ppm}$ demonstrou ser $55 \%$ menor em relação no ponto inicial de análise. Para os outros dois grupos, a densidade aferida nos mesmos pontos correspondeu $13 \%$ e $16 \%$ de perda de intensidade. A matriz do grupo I foi nesse ponto, três vezes mais densa em relação à dos outros grupos. A partir do ponto de $1400 \mu \mathrm{m}$, não foi possível determinar a densidade nos grupos de $7 \mathrm{ppm}$ e controle, mas no grupo de 100ppm isto só ocorreu a partir de $4200 \mu \mathrm{m}$. Neste ponto, a densidade representou 2,4\%, quando comparada ao ponto inicial. Um indicativo da lentidão presente na degradação e reabsorção das proteínas de matriz no grupo de $100 \mathrm{ppm}$.

Os resultados relativos aos comprimentos das matrizes analisadas pela densitometria mostraram que, a medida linear de cada matriz a partir do início da fase de maturação correspondeu a $1812,17 \mu \mathrm{m}, 2063,90 \mu \mathrm{m}$ e $5321,64 \mu \mathrm{m}$, respectivamente para os grupos III, II e I. Dados que contribuíram para a constatação de que a matriz no grupo de $100 p p m$ mantém-se retida e preservada cerca 2,94 vezes mais que a matriz observada no grupo controle. Entre os grupos III e II, não ocorreu diferença estatisticamente significante. Segundo SMITH; 
NANCl; DENBESTEN77, as proteínas do esmalte com fluorose induzida por 100 ppm seriam retidas pelo menos $40 \%$ a mais em relação aos grupos de incisivos de ratos sem fluorose. Os autores sugeriram ainda, que o tratamento crônico de flúor na água seria capaz de levar os ameloblastos a produzirem uma camada mais fina de esmalte, promoveria uma diminuição em altura nas células do órgão do esmalte da zona de maturação, e diminuiria a modulação dos ameloblastos em sua transição na fase de secreção para a de maturação.

O estabelecimento definitivo sobre a patogenia da fluorose dentária certamente encontra-se além de dados morfológicos quantitativos e qualitativos, sejam eles referentes à matriz do esmalte ou à estrutura dos ameloblastos. A fluorose resulta de alterações em diferentes níveis bioquímicos e moleculares durante a amelogênese.

Provavelmente, em breve haverá um consenso em relação aos eventos geradores da fluorose, antes que se esgotem os métodos aplicados ao estudo dessa patologia. A finalidade deste experimento, proposto em tese, está diretamente relacionada com a intenção de contribuir para que, a pesquisa básica forneça à ciência peças a serem delineadas e acrescidas ao conhecimento da fluorose dentária. 


\section{7- CONCLUSÃO}




\section{7 - Conclusão}

Com base na análise dos resultados obtidos e de acordo com a revisão da literatura referente ao assunto proposto, concluiu-se que após seis semanas de tratamento:

1. O padrão de identificação imuno-histoquímica da matriz do esmalte, manteve-se homogêneo na fase de secreção, apresentando variações de intensidade discretas nas fases de transição e maturação do mesmo, indicando possíveis alterações na acessibilidade dos determinantes antigênicos das amelogeninas durante os diferentes estádios da amelogênese.

2. O comprimento linear da matriz produzida e secretada nos grupos experimentais I, II e III foi similar, demonstrando, sob a metodologia aplicada, que o flúor não exerce influência na secreção da matriz do esmalte. A partir da 
fase de transição dos incisivos do grupo I, a matriz permaneceu retida, in situ, em torno de $300 \%$, em relação aos outros grupos.

3. A densitometria demonstrou que a reabsorção das proteínas do esmalte, durante a fase de maturação, se faz de forma mais lenta e gradual nos incisivos dos animais experimentais tratados com fluorose induzida por $100 \mathrm{ppm}$ de água de consumo diário, resultando em um padrão morfológico macroscópico de hipomineralização, caracterizado como fluorose dentária. 


\section{REFERÊNCIAS BIBLIOGRÁFICAS}




\section{Referências Bibliográficas}

1. ANGMAR-MANSSON, B.; WHITFORD, G. M. Single fluoride doses and enamel fluorosis in the rat. Caries Res., v.19, n.2, p.14552, Mar./Apr. 1985.

2. ANGMAR-MANSSON, B.; LINDH, V.; WHITFORD, G. M. Enamel and dentin fluoride levels and fluorosis following single fluoride doses: a nuclear micropobe sdudy. Caries Res., v.24, n.4, p. 258-62, July/Aug. 1990.

3. AOBA, T. et al. Selective absorption of porcine -amelogenins onto hydroxyapatite and their inhibitory activity on hydroxyapatite growth in supersaturated solutions. Calcif. Tiss. Int.,v.41 ,p.281-9, 1987.

4. AOBA, T. et al. Common epitopes of mammalian amelogenins at the C-terminus and possible funtional roles of the 
corresponding domain in enamel mineralization. Calcif. Tiss. Int. , v.51, n.1, p.85-91, July 1992.

5. AOBA, T. The effect of fluoride on apatite structure and growth. Crit. Rev. Oral Biol. Med., v.8, n.2, p.136-53, 1997.

6. ARMSTRONG, W. D. Mechanismis of fluorie homeostasis. Arch. oral Biol., v.4, p.156-9, 1961.

7. AXRUP, K. et al. Children with thalidomide embryopathy: Odontological observations and aspects. Acta Odont. Scand., v.24, p.3, 1966.

8. BAWDEN, J. W.; DEATON, T. G.; CRENSHAW, M. A. Diffusion of fluoride through the rat enamel organ in vitro. J. dent. Res., v.66, p.1360-3, 1987.

9. BAWDEN, J. W. et al. Consideration of possible biologic mechanisms of fluorosis. J. dent. Res., v.74, n.7, p. 1349-52, July 1995. 
10. BHUSSY, B. R. Chemical and physical studies of enamel from human teeth: density and nitrogen content of mottled enamel. J. dent. Res., v.38, p.369-73, 1959.

11. BRÓGLIO, L. A. Z. Estudo cinético do efeito do flúor sangüíneo e ósseo na incorporação ao esmalte dental de animais (Rattus novergicus var. albinus) previamente expostos ou não e submetidos a uma dose única. Piracicaba, 1994. 69p. Tese (Doutorado) - Faculdade de Odontologia de Piracicaba, Universidade Estadual de Campinas.

12. BRONCKERS, A. L. J. J.; WOLTGENS, J. H. M. Short-term effects of fluoride on biosynthesis of enamel-matrix proteins and dentin collagens and on mineralization during hamster tooth-germ development in orgam culture. Arch. oral Biol., v.39, p.181-85, 1984.

13. BRONCKERS, A. L. J. J.; JANSEN, L. L.; WOLTGENS, J. H. M. A histological study of the short-term effects of fluoride on enamel and dentine formation in hamster tooth-germs in 
organ culture in vitro. Arch. oral Biol., v.29, n.10, p.803-10, 1984.

14. CHAPMAN, V. M. et al. Linkage of amelogenin (AMEL) to the distal portion of the mouse X chromosome. Genomics, v.10, p.23-8, 1991.

15. CLARKSON, J. et al. A review of the developmental defectes of enamel index (DDE index). Int. dent. J. , v.42, n.6, p.411-26, 1992.

16. DE LUCA, R. R. et al. Manual para técnicos em bioterismo. 2ed. São Paulo, Winner Graph, 1996. p.157-64.

17. DENBESTEN, P. K. Effects of fluoride on protein secretion and removal during enamel development in the rat. J. dent. Res., v.65, n. 10 , Oct. 1986.

18. DENBENSTEN, P. K. Biological mechanisms of dental fluorosis relevant to the use of fluoride supplements. Community Dent. oral Epidem., v.27, p.41-7, 1999. 
19. DENBENSTEN, P. K. Mechanism and timing of fluoride effects on developing enamel. J. Publ. Hlth Dent., v.59, n.4, p.247-251, Fall 1999.

20. DenBeSten,P. K.; CRENSHAW, M. A. The effects of chronic high fluoride levels on forming enamel in the rat. Arch. oral Biol., v.29, n.9, p.675-9, 1984.

21. DenbeSten, P. K.; CREShAW, M. A.; WILSON, M. H. Changes in the fluoride modulation of maturation stage ameloblasts of rats. J. dent. Res., v.64, p.1365-70, 1985.

22. DENBENSTEN, P. K. et al. Fluoride binding by matrix proteins in rat mineralizing tissue. Arch. oral Biol., v.37, n.6, p.459-62, 1992.

23. DIEKWISK, T. G. H. et al. Immunohistochemical similarities and differences between amelogenin and tuftelin gene products during tooth development. J. Histochem. Cytochem., v.45, n.6, p.859-66, June 1997. 
24. DOHI, N. et al. Immunocytochemical and immunochemical study of enamelins, using antibodies against porcine $89-\mathrm{kDa}$ enamelin and its $\mathrm{N}$-terminal synthetic peptide, in porcine tooth germs. Cell Tiss. Res., v.293, n.2, v.313-25, 1998.

25. EASTOE, J. E. Enamel protein chemistry - past, present and future. J. dent. Res., v. 58, p.753-63, Mar. 1979. Special issue B.

26. EASTOE, J. E. The chemical composition of bone and tooth. Adv. Fluorine Res. dent. Caries Prev., v.3, p.5-16, 1965.

27. FEJERSKOV, O.; YAEGER, J. A.; THYLSTRUP, A. Microradiography of acute and chronic administration of fluoride on humam and rat dentine and enamel. Arch. oral Biol., v.24, p.123-30, 1979.

28. FEJERSKOV, O. et al. Dental tissue effects of fluoride. Adv. dent. Res., v.8, n.1, p.15-31, June 1994.

29. FINCHAN, A. G.; SIMMER, J. P. Amelogenin proteins of developing dental enamel. Ciba Found. Symmp., v.205, p.1 18-34, 1997. 
30. FINCHAM, A. G.; MORADIAN-OLDAK, J.; SIMMER, J. P. The structural biology of the developing dental enamel matrix. J. struct. Biol.,v.126, p. 270-99, 1999.

31. FINCHAM, A. G. et al. Dental enamel matrix: sequences of two amelogenin polypeptides. Biosci. Rep., v.1, p.771-8, 1981.

32. FINCHAM, A. G. et al. Evidence for amelogenin "nanospheres" as functional components of secretory-stage enamel matrix. J. Struc. Biol., v.115, n.1, p.50-9, July 1995.

33. FUKAE, M. et al. Enamelysin (matrix metalloproteinase-20): Localization in the developing tooth and effects of $\mathrm{pH}$ and calcium on amelogenin hydrolises. J. dent. Res., v.77, n.8, p.1580-8, 1998.

34. GERLACH, R. F. et al. Fluoride effect on the activity of enamel matrix proteinases in vitro. Europ. J. oral Sci., v.108, n.1, p.4853, Feb. 2000. 
35. GIBSON, C. W. et al. Identification ofleucine-rich amelogenin peptide (LRAP) as the translation product of alternatively spliced transcrip. Biochem. Biophys Res. Comm., v.174, p.1306-12, 1991.

36. GRAVER, H. T.; CHRISTNER, P. Immunohistochemical localization of amelogenins in enameloid of lower vertebrate teeth. Science, v.207, n.21, p.1357-8, Mar. 1980.

37. HOLLAND, R. I.; HONGSLO, J. K. The effect of fluoride on the cellular uptake and pool of amino acids. Acta. Pharmacol. Toxicol., v.44, p. 354-8, 1979.

38. HU, C. C. et al. Cloning, cDNA sequence, and alternative splicing of porcine amelogenin mRNAs. J. dent. Res., v.75, n.10, p.1735-41, Oct. 1996.

39. HU, C.-C. et al. Sheathlin: Cloning, cDNA polypeptide sequences, and immunolocalization of porcine enamel sheath proteins. J. dent. Res., v.766, n.2, p.648-57, Feb. 1997. 
40. KRUGER, B. J. The effect of diferent levels of fluoride on the ultrastructure of ameloblasts in rat. Arch. oral Biol., v.15, n.2, p.109-14, 1970.

41. KRUGER, B. J. Utilization of $3 \mathrm{H}$-serine by ameloblasts receiving sub-mottling doses of fluoride. Arch. oral Biol., v.17, p.138994, 1972.

42. KURISU, K.; TABATA, M. J. Human genes for dental anomalies. Oral Dis., v.3, n.4, p.223-8, Dec. 1997.

43. LANGE, N. A. et al. Fluoride-induced cystic changes in the enamel organ of the rat molar. J. oral Path., v.15, p.87-92, 1986.

44. LAU, E. C.et al. Human and mouse amelogenin gene loci are on the Sex chromosomes. Genomics, v.4, p.162-8, 1989.

45. LOWENSTAM, H. A. Minerals formed by organisms. Science, v.211, n.4481, p.1126-31, Mar. 1981. 
46. LUMSDEN. A. G. S. et al. Spatial organization of the epithelium and the role of neural crest cells in the initiation of the mammalian tooth germ. Development, v.103, p.155-169, 1988. Supplement.

47. LYARUU, D.M. et al. Ultraestructure of in vitro recovery of mineralization capacity of fluorotic enamel matrix in hamster tooth germs pre-exposed to fluoride in organ culture during the secretory phase of amelogenesis. Arch. oral Biol., v.32, p.107-15, 1987.

48. MILES, A. E. W.; GRIGSON, C. Colyer's variations and diseases of the teeth of animals. New York, Cambridge University Press, 1990. p.437-54.

49. NAKAHORI, Y.; TAKENAKA, O.; NAKAGOME, Y. A human $X-Y$ homologous region encodes amelogenin. Genomics, v.9, p.264-9, 1991.

50. NANCI, A.; SLAVKIN, H. C.; SMITH, C. E. Application of highresolution immunocytochemistry to the study of the secretory, 
resorptive, and degradative functions of ameloblasts. Adv. dent. Res., v.1, n.2, p.148-61, Dec. 1987.

51. NANCl, A. et al. Comparative immunohistochemical analyses of the developmental expression and distribution of ameloblastin and amelogenin in rat incisors. J. Histochem. Cytochem., v.46, n.8, p.911-34, Aug. 1998.

52. OLIVEIRA, D. T. Efeito crônico do flúor no esmalte e nos ameloblastos secretores de incisivos de ratos. Piracicaba, 1988. 47p. Dissertação (Mestrado) - Faculdade de Odontologia de Piracicaba, Universidade Estadual de Campinas.

53. OVERALL, C.M.; LIMEBACK, H. Identification and characterization of enamel proteinases isolated from developing enamel. Biochem. J., v. 256, p. 965-72, 1988.

54. PIEZ, K. A. The nature of the protein matrix of humam enamel. J. dent. Res., v.39, n.4, p.712, July 1960. /Abstract n.169/ 
55. PINDBORG, J. J. Aetiolgy of developmental enamel defects not related to fluorosis. Int. dent. J., v.32, n.2, p.123-34, 1982.

56. PONDER, B. A.; WILKINSON, M. M. Inhibition of endogenous tissue alkaline phosphatase with the use of alkaline phosphatase conjugates in immunohistochemistry. J. Histochem. Cytochem., v.29, n.8, p.981-4, 1981.

57. REITH, E. J. The stages of amelogenesis as observed in molar teeth of young rats. J. Ultrastruct. Res., v.30, p.111-51, 1970.

58. RICHARDS, A. Nature and mechanisms of dental fluorosis in animals. J. dent. Res., v.69, p.701-5, Feb. 1990. Special issue.

59. ROBINSON, C.; BROOKES, S. J.; BONASS, W. A. Enamel maturation. Ciba Found. Symp., v.205, p.156-70, 1997.

60. ROBINSON, C.; KIRKHAM, J.; HALLSWORTH, A. S. Volume distribution and concentration of protein, mineral and water in developing bovine enamel. Ach. oral Biol., v.33, p. 159-162, 1988. 
61. ROBINSON, C. et al. Enamel proteins: From secretion to maturation. J. dent. Res., v.61, p.1490-5, Dec. 1982. Special issue

62. ROBINSON, C. et al. The developing enamel matrix: nature and function. Europ. J. oral Sci., v.106, p.282-91, Jan. 1998. Supplement 1.

63. ROHANIZADEH, R. et al. Ultrastructural organization and microanalysis studies of deciduous enamel crystallites in regional odontodysplasia. J. Oral Path. Med., v.27, n.10, p.5017, Nov. 1998.

64. SALIDO, E. C. et al. The human enamel protein gene amelogenin is expressed from both $X$ and $Y$ chromosomes. Amer. J. Hum. Gen., v.50, n.303-16, 1991.

65. SASAKI, S.; SHIMOKAWA, S. Enamel proteins: biosyntesis and chemistry. J. dent. Res., v.58B, p.765-71, Mar. 1979. 
66. SASAKI, T.; TAKAGI, M.; YANAGISAWA, T. Structure and function of secretory ameloblasts in enamel formation. Ciba Found Symp., v. 205, p.32-46, 1997.

67. SCHOUR, I.; MASSLER, M. The Teeth. In: FARRIS, E.J.; GRIFFTH Junior., J. Q. The rat in laboratory investigation. Philadelphia, Lippincott, 1949. p. 104-65.

68. SHINODA, H. Efftect of long-term administration of fluoride on physico-chemical properties of the rat incisor enamel. Calcif. Tiss. Res., v. 18, p.91-100, 1975.

69. SHORE, R. C. et al. An immunohistochemical study of the effects of fuoride on enamel development in the rat incisor. Arch. oral Biol., v.38, n.7, p.607-10, June 1993.

70. SHUPE, J.L. Clinical and pathological effects of fluoride toxicity in animals. Ciba Found. Symp., v.2, p.357-88, 1971.

71. SIMMER, J. P. Alternative splicing of amelogenins. Connect. Tiss. Res., v.32, p.131-6, 1995. 
72. SIMMER, J. P.; FINCHAN, A. G. Molecular mechanisms of dental enamel formation. Crit. Rev. oral Biol. Med., v.6, n.2, p.84-108, 1995.

73. SIMMER, J. P. et al. Isolation and characterization of a mouse amelogenin expressed in Escherichia coli. Calcif. Tiss. Int., v.54, n.4, p.312-9, Apr. 1994.

74. SINGER, L.; ARMSTRONG, W. D. Regulation of human plasma fluoride concentration. J. appl. Physiol., v.15, n.3, p.219-33, Sept. 1960.

75. SMALES, F. C. Structural sub-units in prisms of immature rat enamel. Nature, v.258,p.772-4, 1975.

76. SMITH, C. E.; NANCI, A. A method for sampling the stages of amelogenesis on mandibular rat incisors using the molars as a reference for dissection. Anat. Rec., v. 225, p.257-66, 1989.

77. SMITH, C. E.; NANCI, A.; DENBESTEN, P. K. Effects of chronic fluoride exposure on morphometric parameters defining the 
stages of amelogenesis and ameloblast modulation in rat incisors. Anat. Rec., v.237, p.243-58, 1993.

78. SNEAD, M. L.. DNA sequence for clone CDNA for murine amelogenin reveal the amino acid sequence for enamelspecific protein. Biochem. Biophys. Res. Comm., v.129, n.3, p.812-8, June 1985.

79. SNEAD, M. L. et al. Construction ad identification of mouse amelogenin cDNA clones. Proc. Natl. Acad. Sci. USA, v.80, n. 23, p.7254-8, Dec. 1983.

80. SUGA, S. Histochemical observations of proteolytic enzyme activity in the developing dental hard tissues of the rat. Arch. oral Biol., v.15, p.555-8, 1970.

81. SUGA, S. Progressive mineralization pattern of developing enamel during the maturation stage. J. dent. Res., v.61, p.1532-1542, 1982. Special issue. 
82. SUGA, S. Enamel hypomineralization viewed from the pattern of progressive mineralization of human and monkey developing enamel. Adv. dent. Res., v.3, p.188-98, 1989.

83. SUGA, S. et al. A comparative study of disturbed mineralization of rat incisor enamel induced by strontium and fluoride administration. Adv. dent. Res., v.1, n.2, p.339-55, Dec. 1987.

84. SUKLING, G. W. History of the DDE indices. N. Z. dent. J., v.94, n.415, p.9-11, Mar. 1998.

85. SUKLING, G.; ELLIOTT, D. C.; THURLEY, D. C. The macroscopic appearance and associated histological changes in the enamel organ of hypoplastic lesions of sheep incisor teeth resulting from induced parasitism. Arch. oral Biol., v.31, p.427-39, 1986.

86. TANABE, $T$. et al. Effect of fluoride in apatite lattice on adsorption of enamel proteins onto calcium apatites. J. dent. Res., v.67, n. 3, p.536-42, 1988. 
87. TAN, J. et al. Quantitative analysis of amelogenin solubility. J. dent. Res., v.77, n.6, p.1388-96, June 1998.

88. TANIGUCHI, K. et al. The effect of mechanical trauma on the tooth germ of rat molars at various developmental stages: a histopathological study. Endod. dent. Traumat., v.15, n.1, p.17-25, Feb. 1999.

89. KATCHBURIAN, E.; ARANA-CHAVES, V. E. Histologia e embriologia oral. 1ed. São Paulo, Panamericana, 1998.

90. TERMINE, J. D. et al. Propreties of dissociatively extrated fetal tooth matrix proteins. Principal molecular species in developing bovine enamel. J. Biol Chem., v.20, p.9760-68, 1980.

91. THESLEFF, I.; ÅBERT, T. Tooth morphogenesis and the differentiation of ameloblasts. Ciba Found. Symp., v.205, p.312, 1997. 
92. TRAVIS, D. F.; GLIMCHER, M. J. The structure and organization of, and the relationships betwen the organic matrix and the inorganic crystals of embryonic bovine enamel. J. Cell Biol., v. 23, p.477-97, 1964.

93. UCHIDA, T. Sheat proteins: Synthesis, secretion, degradation and fate in forming enamel. Europ. J. oral Sci., v.106, p.308-14, 1998.

94. WARSHAWSKY, H.; MOORE, G. A. Techniqque for the fixation and decalcification of rat incisors for electron microscopy. J. Histochem. Cytochem., v.15, n.9, p.542-9, 1967.

95. ZHOU, R.; ZAKI, A. E.; EISENMANN, D. R. Morphometry and autoradiography of altered rat enamel protein processing due to chronic exposure to fluoride. Arch. oral Biol., v.41, n.8/9, p.739-47, Aug. 1996. 
ABSTRACT 


\section{Abstract}

Amelogenins represents the major dental enamel protein motif and its posttransitional retention comes as one of the main factors related to fluorosis pathogenesis. The amelogenins distribution pattern in fluorotic teeth was described by immunohistochemistry and the length of organic matrix was determined by morfometric analysis. Fifteen rats were divided in three groups and treated for 42 days with $100 \mathrm{ppm}$ sodium fluoride, $7 \mathrm{ppm}$ and with deionizaded water. The immunohistochemistry results displaied amelogenins in a by heterogeneous way, indicating possible variations in the proteins epitopes exposition. The results of morfometric analysis at matrix secretion allowed the verification of no significant differences betwen the group with $7 \mathrm{ppm}$ and with deionizaded water. In group with fluorosis induced by $100 \mathrm{ppm}$, the matrix length was $300 \%$ longer, whem compared to the other tested groups. It was observed although, that matrix optical density stayed denser and homogeneous after the beginning of the maturation phase, indicating its post-transitional retention. It was ended, front to the adopted methodology, that $100 \mathrm{ppm}$ of sodium fluoride reserves the capacity to retain the enamel proteins along the maturation phase, where they should be resorperd. The result is a hypomineralized pattern, characteristic of the dental fluorosis. 